IZA DP No. 8400

The Impact of the Global Financial Crisis on Youth Labour Markets

P.N. (Raja) Junankar

August 2014 


\title{
The Impact of the Global Financial Crisis on Youth Labour Markets
}

\author{
P.N. (Raja) Junankar \\ University of New South Wales, \\ University of Western Sydney and IZA
}

Discussion Paper No. 8400 August 2014

IZA
P.O. Box 7240
53072 Bonn
Germany

Phone: +49-228-3894-0

Fax: +49-228-3894-180

E-mail: iza@iza.org

Any opinions expressed here are those of the author(s) and not those of IZA. Research published in this series may include views on policy, but the institute itself takes no institutional policy positions. The IZA research network is committed to the IZA Guiding Principles of Research Integrity.

The Institute for the Study of Labor (IZA) in Bonn is a local and virtual international research center and a place of communication between science, politics and business. IZA is an independent nonprofit organization supported by Deutsche Post Foundation. The center is associated with the University of Bonn and offers a stimulating research environment through its international network, workshops and conferences, data service, project support, research visits and doctoral program. IZA engages in (i) original and internationally competitive research in all fields of labor economics, (ii) development of policy concepts, and (iii) dissemination of research results and concepts to the interested public.

IZA Discussion Papers often represent preliminary work and are circulated to encourage discussion. Citation of such a paper should account for its provisional character. A revised version may be available directly from the author. 
IZA Discussion Paper No. 8400

August 2014

\begin{abstract}
The Impact of the Global Financial Crisis on Youth Labour Markets

This paper investigates the impact of the GFC on youth unemployment and long term unemployment. In particular, we study whether the GFC had a bigger impact on youths than adults, and whether youth unemployment rates increased due to an increase in youth wages relative to adult wages. To anticipate our results, we find that the youth unemployment rates increased significantly more than that of adults even though youth wages had been falling relative to adult wages.
\end{abstract}

JEL Classification: J64, J21

Keywords: $\quad$ youth labour markets, youth unemployment, global financial crisis

Corresponding author:

P.N. (Raja) Junankar

The Australian School of Business

The University of New South Wales

UNSW Sydney NSW 2052

Australia

E-mail:raja.junankar@uws.edu.au 


\section{The Impact of the Global Financial Crisis on Youth Labour Markets ${ }^{1}$}

\section{Introduction}

Australia was one of the few OECD countries to emerge from the Global Financial Crisis (GFC) without facing a recession, usually defined as negative GDP growth for two consecutive quarters. However, the (overall) unemployment rate did increase following the GFC and has still not returned to the pre-GFC levels. Unemployment rates for youths went up much more dramatically and remain high. This paper investigates the impact of the GFC on youth unemployment and long term unemployment. In particular, we study whether the GFC had a bigger impact on youths than adults, and whether youth unemployment rates increased due to an increase in youth wages relative to adult wages. To anticipate our results, we find that the youth unemployment rates increased significantly more than that of adults even though youth wages had been falling relative to adult wages.

The recent changes announced in the Coalition Budget (but as yet not legislated) mean that anyone below 30 years of age will not have access to unemployment benefits for six months and after that would be required to engage in compulsory work for the dole. The prospects for a large and growing number of youths are grim. There has been recent work ${ }^{2}$ that shows that taking on a job that is below the skills of the person leads to a scarring effect: the probability of getting a good job (i.e. appropriate for that person's skills and education levels) are decreased significantly. The Coalition Government has now proposed that anyone under the age of 30 to take any job at all as they would not receive unemployment benefits. This is a policy that will create havoc amongst the young.

\section{Literature Review}

There has been much written about youth labour markets in the OECD in general, and a few papers about the Australian experience. Many of the European OECD countries have faced a massive increase in youth unemployment and long term unemployment. A common feature of this literature is the social impact of youth unemployment. When young people are unemployed they may face various problems including social alienation, depression, an increase in the use of non-prescribed drugs, petty crime, and suicide, see Eurofound (2014).

In the economics literature there has been a continuing debate about the impact of minimum wages on (youth) unemployment with the traditional view assuming competitive labour markets where it is argued that minimum wages leads to unemployment. This view has been very popular with Conservative politicians and with the business sector. However, in recent

\footnotetext{
${ }^{1}$ I am grateful to Michael Quinlan (UNSW), Peter Kriesler (UNSW), and Matt Cowgill (ACTU) for comments that have helped to improve the paper. I am, of course, responsible for remaining errors.

${ }^{2}$ Clark et al. (2014), Mavromaras et al. (2013), Stewart (2007).
} 
years a growing number of economists have argued that in imperfect markets, minimum wages do not lead to unemployment, see Card and Kreuger (1995), Manning (2003, 2010), Booth (2014). They argue that the labour market is not a perfectly competitive market but employers have market power in wage setting (monopsony). There is asymmetric information in the labour market, workers have heterogeneous preferences, etc. which make the labour market behave differently from a competitive market. Manning $(2003,2010)$ has shown that in such markets employment can increase with an increase in wage rates.

It is interesting that the OECD (1998) which normally argues for flexibility of wages, found that:

"Firstly, the results suggest that a rise in the minimum wage has a negative effect on teenage employment. Secondly, negative employment effects for young adults are generally close to or insignificantly different from zero. Thirdly, for prime-age adults, the most plausible specifications suggest that minimum wages have no impact on their employment outcomes." (OECD Employment Outlook 1998, pp. 47-48)

However, they are cautious in their conclusion and emphasise the "fragility of the results in Table 2.5", (OECD 1998, p. 47, emphasis added). They add:

"At the same time, it is important to note that these estimated effects are relatively insignificant in terms of explaining the large decline that has occurred in the teenage employment-population ratio in some countries." (OECD Employment Outlook 1998, p. 48)

There is another branch of traditional economics that argues that generous unemployment benefits lead to increased unemployment. The underlying economic theory is based on a model of unemployed workers searching for a job with imperfect information; see Mortensen and Pissarides (1999). The unemployed searching for employment receive various job offers, but depending on the wage offered they may accept or reject that offer. If they have substantial unemployment benefits they have a higher "reservation wage" and they reject low wage offers and remain unemployed. In various papers Layard and Nickell have argued that unemployment benefits are one of the reasons for high unemployment. They also argue that various labour market institutions like unions, centralised wage bargaining, etc. also lead to higher unemployment, see Nickell and Layard (1999). These results have been criticised by various people including Howell et al. (2005, 2007). Heckman (2007) in his comment also argue that the orthodox results are "fragile" and cannot support the conclusions that labour market institutions are the main cause of high unemployment.

Curiously there is a very limited amount of recent literature on Australian Youth Labour Markets. There were a few survey papers several years ago, see Miller and Volker (1987), Lewis \& Mclean (1998), a few papers using longitudinal data, Junankar and Wood (1992), Marks et al. (2003), and some time series estimates of employment, Daly et al. (1998) and Junankar, Waite and Belchamber (2000). These papers find contradictory results and there is no clear consensus. However, there is some evidence for scarring and occurrence dependence (an event of unemployment increases the probability of repeat spell). A relatively recent paper by Doiron and Gorgens (2008) finds evidence for state dependence using the 
Household and Income Labour Dynamics (HILDA) longitudinal data. Another recent paper by Hérault et al. (2012) estimate a multinomial logit model for the youth labour market (using cohort data from the Longitudinal Surveys of Australian Youth, and Youth in Transition Surveys) and find that the effects of growth and unemployment affect different components of the youth labour market differently. An increase in the overall unemployment rate increases the risk of unemployment.

\section{The Youth Labour Market ${ }^{3}$}

The youth labour market is a complex market: young people have a choice of leaving school at age 16 or 17 (the compulsory schooling ages) or continue until age 18 (and complete year 12). If they leave school early, they may look for work or a traineeship. If they continue until age 18, they may look for work or continue in tertiary education (either at a TAFE or at University). As the number of unskilled jobs seem to have been on a declining trend over the past few decades, most young people who leave school early find it difficult to get a job. As a result, they may decide to re-enter the education sector. If they continue into tertiary education, they may leave education at 20 (say with a TAFE qualification) or a university degree at 21 or 22 .

Many young people who are studying at TAFE or University often work part-time as well. There is even a significant number of young people who are full-time students and who work full-time! There are large flows between different states: from employment to unemployment or education, from unemployment to education or employment, and from education to employment or unemployment.

Since there is a surge of young people entering the labour market at the end of a school year or university year, the sudden increase in supply means that it is difficult to find a job quickly and unemployment rises. If some young people are unable to find work for some time, they may move from unemployment to the education sector, the not-in-the-labour force (NILF) state, and the labour force participation rate falls and unemployment falls. In a recession, as firms stop hiring it hits the young as they are just entering the labour market. In addition, during a recession firms tend to fire the young as they work on a Last-in-First-Out basis. As many young people may be in casual or short term employment, during a recession these contracts are not renewed. Another important feature of the youth labour market is that young people are typically employed in cyclically sensitive areas like manufacturing and construction (for males) and Retail trade and Accommodation and food services (especially for females), see Table 1. During the GFC these industries were hit significantly and youth unemployment increases substantially.

As a result, young people are likely to face higher rates of unemployment compared to adults, see Figure 1. As young people see the labour market getting tighter they may respond by delaying entering the labour market and continue their education (what I call "encouraged students"). Similarly, when people have been unemployed for a long period they may give up searching for employment (the "discouraged workers").

\footnotetext{
${ }^{3}$ See Chris Sewell (2013) for an extended literature review and econometric analysis.
} 


\section{Figure 1: Unemployment Rates}

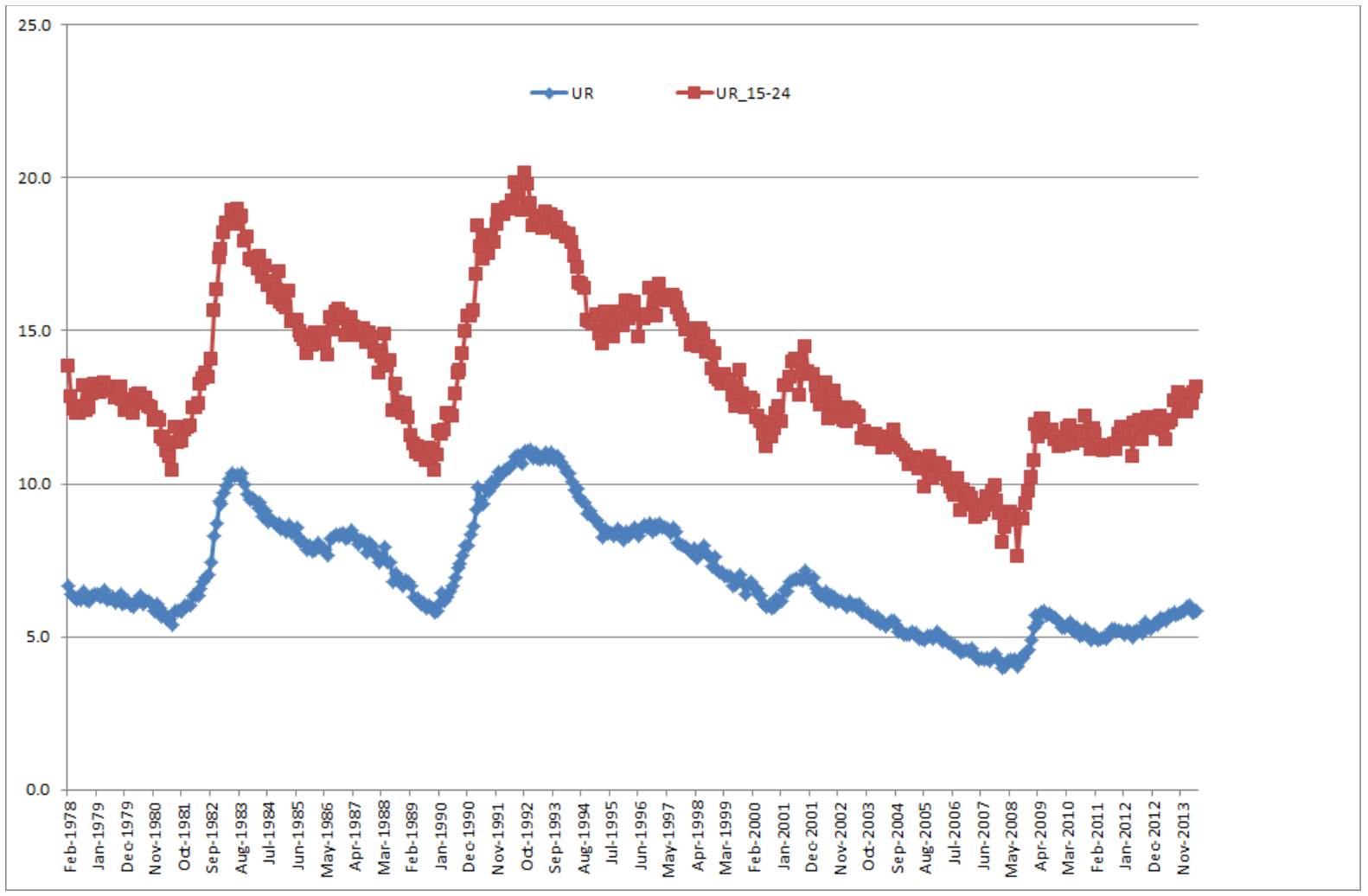

Source: ABS 6202002 and 6202017

A simple ordinary least squares regression of youth unemployment (15-24) on total unemployment gives the following:

$$
\begin{gathered}
\text { YUR }=3.35+1.45 \mathrm{UR} \\
(18.5)(58.1) \\
\mathrm{R}^{2}=0.96
\end{gathered}
$$

In words, for every one percent increase in the overall unemployment rate youth unemployment rate increases by 1.45 percentage points.

There appears to be a change in this relationship after the GFC:

$$
\begin{gathered}
\text { YUR }=2.92+1.50 \mathrm{UR}+0.50 \mathrm{GFC} \\
(14.3) \quad(55.8) \\
\mathrm{R}^{2}=0.96
\end{gathered}
$$

Which shows that, for every one percentage point increase in the overall unemployment rate youth unemployment rate increases by 1.50 percentage points and after the GFC by an additional 0.50 percentage points. In each case the variables are statistically significant at the one percent levels ${ }^{4}$.

A similar equation was estimated in terms of an annual change in unemployment rates (to remove any trend):

\footnotetext{
${ }^{4}$ This is a purely descriptive statement, and not a causal statement. In fact, the overall unemployment rate contains youth unemployment.
} 
Change in YUR $=0.12+1.72$ Change in UR

$$
\begin{gathered}
(0.25) \quad(37.52) \\
\mathrm{R}^{2}=0.91
\end{gathered}
$$

This suggests that an increase of one percentage point in the total unemployment rate of leads to 1.72 percentage points increase in youth unemployment rate.

Although youths are usually defined as young people between the ages of 15 and 24, the labour market for the 15-19 is very different from that of the 20-24 age group. Young people are more likely to be working part time or in casual jobs. Figures 1 and 2 show that for young males and females (15-19) a majority are part-time workers, but even for the age group 20-24 a large proportion of them are working in part-time jobs. In addition, there has been a significant increase in part-time working for young males and females over the past decades. A very high proportion of part-time jobs are casual jobs and hence they are more likely to lose their jobs when a recession hits. 
Table 1: Youth Shares of Employment by Age and Industry, 2011 (\%)

\begin{tabular}{|l|c|c|c|c|} 
Males, 15-19 and 20-24 (May Quarter 2014) & $\begin{array}{l}\text { MEFT, 15- } \\
\mathbf{1 9}(\%)\end{array}$ & $\begin{array}{l}\text { MEPT 15- } \\
\mathbf{1 9}(\%)\end{array}$ & $\begin{array}{l}\text { MEFT 20- } \\
\mathbf{2 4}(\%)\end{array}$ & $\begin{array}{l}\text { MEPT 20- } \\
\mathbf{2 4}(\%)\end{array}$ \\
\hline Agriculture, Forestry and Fishing & 4.59 & 2.08 & 3.27 & 0.42 \\
\hline Mining & 0.63 & 0.15 & 4.57 & 0.26 \\
\hline Manufacturing & $\mathbf{1 1 . 4 3}$ & 2.38 & $\mathbf{1 0 . 2 9}$ & $\mathbf{4 . 0 8}$ \\
\hline Electricity, Gas, Water and Waste Services & 2.52 & 0.10 & 1.05 & 0.26 \\
\hline Construction & $\mathbf{3 4 . 2 9}$ & 2.67 & $\mathbf{2 5 . 5 2}$ & 6.84 \\
\hline Wholesale Trade & 2.70 & 1.14 & 2.80 & 0.68 \\
\hline Retail Trade & $\mathbf{1 2 . 0 6}$ & $\mathbf{3 5 . 8 9}$ & $\mathbf{1 0 . 2 9}$ & $\mathbf{2 6 . 2 8}$ \\
\hline Accommodation and Food Services & 5.76 & $\mathbf{3 5 . 2 5}$ & 6.69 & $\mathbf{2 1 . 3 7}$ \\
\hline Transport, Postal and Warehousing & 4.41 & 1.98 & 5.24 & 5.49 \\
\hline Information Media and Telecommunications & 3.06 & 0.69 & 2.17 & 1.57 \\
\hline Financial and Insurance Services & & 0.20 & 1.52 & 0.89 \\
\hline Rental, Hiring and Real Estate Services & 0.18 & 1.04 & 1.05 & 2.77 \\
\hline Professional, Scientific and Technical Services & 2.34 & 2.52 & 4.89 & 2.66 \\
\hline Administrative and Support Services & 0.63 & 2.48 & 2.10 & 3.61 \\
\hline Public Administration and Safety & 2.61 & & 3.60 & 2.35 \\
\hline Education and Training & 0.72 & 1.83 & 1.12 & 5.12 \\
\hline Health Care and Social Assistance & 0.72 & 2.52 & 2.90 & 7.37 \\
\hline Arts and Recreation Services & 1.17 & 5.69 & 2.05 & 5.49 \\
\hline Other Services & $\mathbf{1 0 . 1 7}$ & 1.39 & 8.89 & 2.51 \\
\hline Total (000's) & 111.1 & 202 & 400.5 & 191.4 \\
\hline & & & & \\
\hline
\end{tabular}

\begin{tabular}{|l|c|c|c|c|}
\hline Females 15-19, 20-24 (May Quarter 2014) & $\begin{array}{l}\text { FEFT 15- } \\
\mathbf{1 9}(\%)\end{array}$ & $\begin{array}{l}\text { FEPT 15- } \\
\mathbf{1 9}(\%)\end{array}$ & $\begin{array}{l}\text { FEFT 20- } \\
\mathbf{2 4}(\%)\end{array}$ & $\begin{array}{l}\text { FEPT 20- } \\
\mathbf{2 4}(\%)\end{array}$ \\
\hline Agriculture, Forestry and Fishing & 0.71 & 0.52 & 1.08 & 0.25 \\
\hline Mining & & & 0.97 & 0.11 \\
\hline Manufacturing & 7.30 & 4.19 & 3.95 & 2.64 \\
\hline Electricity, Gas, Water and Waste Services & 0.89 & & 0.68 & 0.32 \\
\hline Construction & 1.07 & 0.26 & 1.69 & 1.00 \\
\hline Wholesale Trade & 0.53 & 0.33 & 2.55 & 0.64 \\
\hline Retail Trade & $\mathbf{1 7 . 2 6}$ & $\mathbf{3 6 . 0 0}$ & $\mathbf{1 2 . 0 3}$ & $\mathbf{3 0 . 3 1}$ \\
\hline Accommodation and Food Services & $\mathbf{1 5 . 6 6}$ & $\mathbf{3 8 . 8 6}$ & 8.04 & $\mathbf{2 1 . 4 3}$ \\
\hline Transport, Postal and Warehousing & 3.20 & 0.96 & 3.59 & 1.57 \\
\hline Information Media and Telecommunications & 2.14 & 1.15 & 1.26 & 2.46 \\
\hline Financial and Insurance Services & 3.74 & 0.30 & 5.10 & 1.07 \\
\hline Rental, Hiring and Real Estate Services & 3.91 & 1.45 & 5.46 & 1.82 \\
\hline Professional, Scientific and Technical Services & 5.16 & 0.85 & $\mathbf{1 0 . 9 9}$ & 3.21 \\
\hline Administrative and Support Services & 1.42 & 0.89 & 2.37 & 2.82 \\
\hline Public Administration and Safety & 2.67 & 0.04 & 6.93 & 1.43 \\
\hline Education and Training & 3.02 & 3.23 & 5.82 & 8.06 \\
\hline Health Care and Social Assistance & $\mathbf{1 7 . 4 4}$ & 4.60 & $\mathbf{1 9 . 4 6}$ & $\mathbf{1 2 . 7 0}$ \\
\hline Arts and Recreation Services & 0.89 & 3.34 & 1.22 & 3.74 \\
\hline Other Services & $\mathbf{1 2 . 9 9}$ & 3.04 & 6.82 & 4.42 \\
\hline Total (000's) & 56.2 & 269.7 & 278.5 & 280.4 \\
\hline
\end{tabular}


Source: ABS Employed persons (ST E12)

Notes:

MEFT $=$ Share of Males Employed Full Time in Industry $\mathrm{x}$

MEPT $=$ Share of Males Employed Part Time in Industry $\mathrm{x}$

FEFT $=$ Share of Females Employed Full Time in Industry $\mathrm{x}$

FEPT $=$ Share of Females Employed Part Time in Industry $\mathrm{x}$

Young people are more likely to be working part time or in casual jobs. As Figures 2 and 3 show that for young males and females (15-19) a large majority are part-time workers, but even for the age group 20-24 a significant proportion of them are working in part-time jobs. In addition, there has been a significant increase in part-time working for young males and females. As we can see from Figures 4 and 5, part-time workers are more likely to be casual workers and hence subject to a greater threat of losing their jobs. Even a large proportion of young full time workers are in casual employment, and would most likely be the first to lose their jobs in a recession.

Figure 2: Share of Part Time Employment in Total (\%), Males 15-19 and 20-24

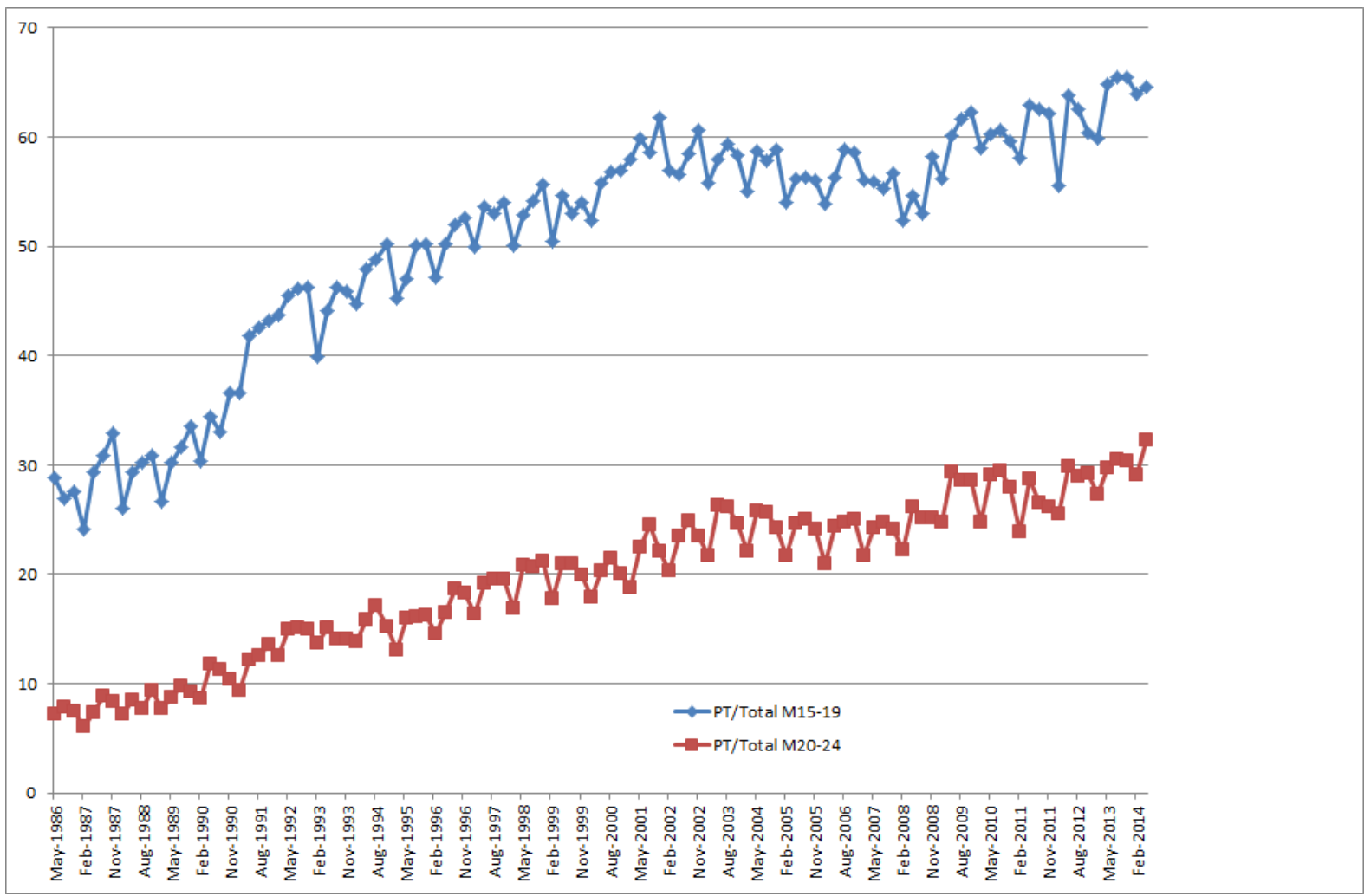

Source: 6291.0.55.001 Labour Force, Australia, Detailed - Electronic Delivery, Table 3a 
Figure 3: Share of Part Time Employment in Total, Females 15-19 and 20-24

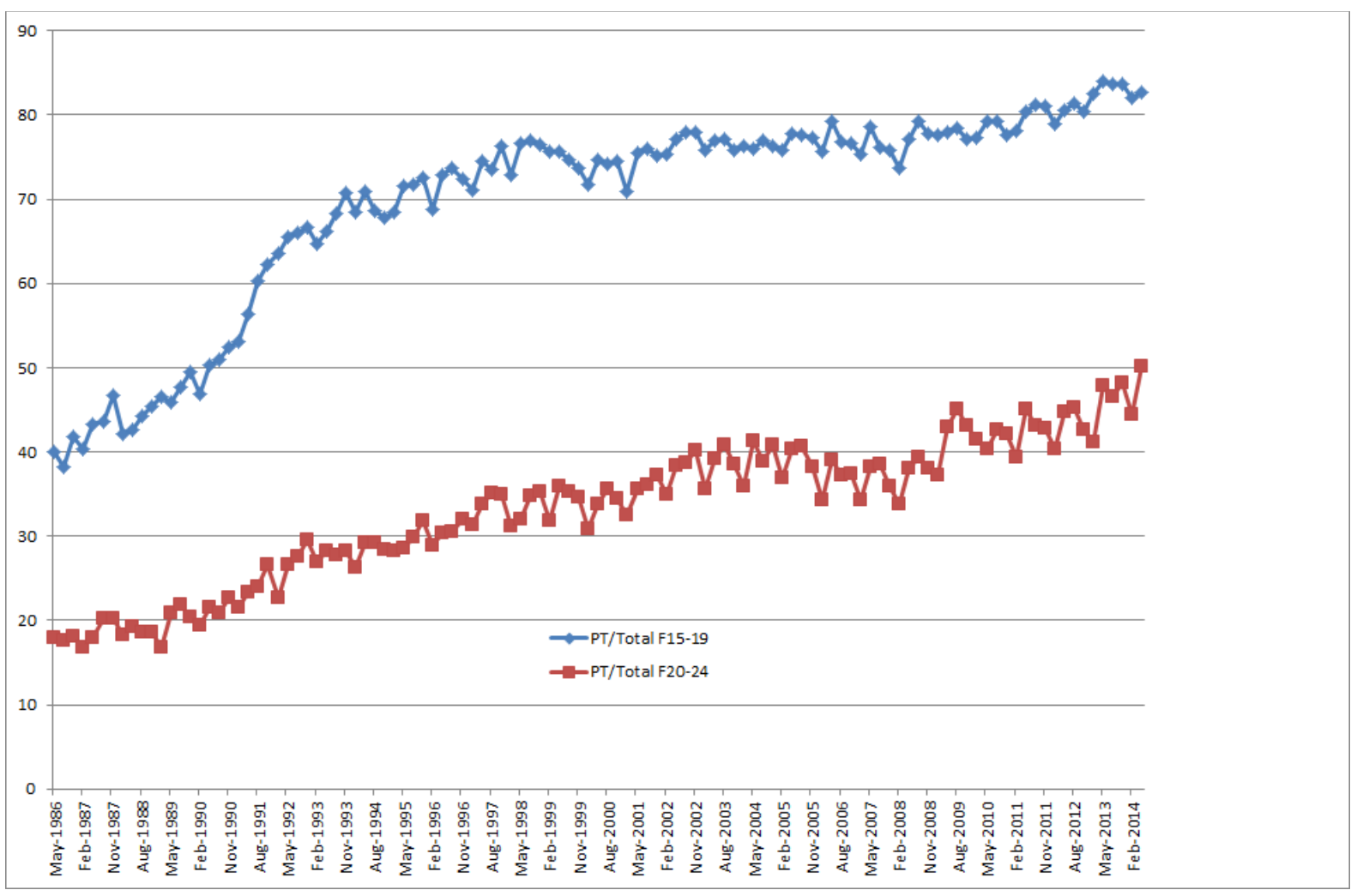

Source: 6291.0.55.001 Labour Force, Australia, Detailed - Electronic Delivery, Table 3a

Figure 4: Share of Male Casual Workers in Total Employment

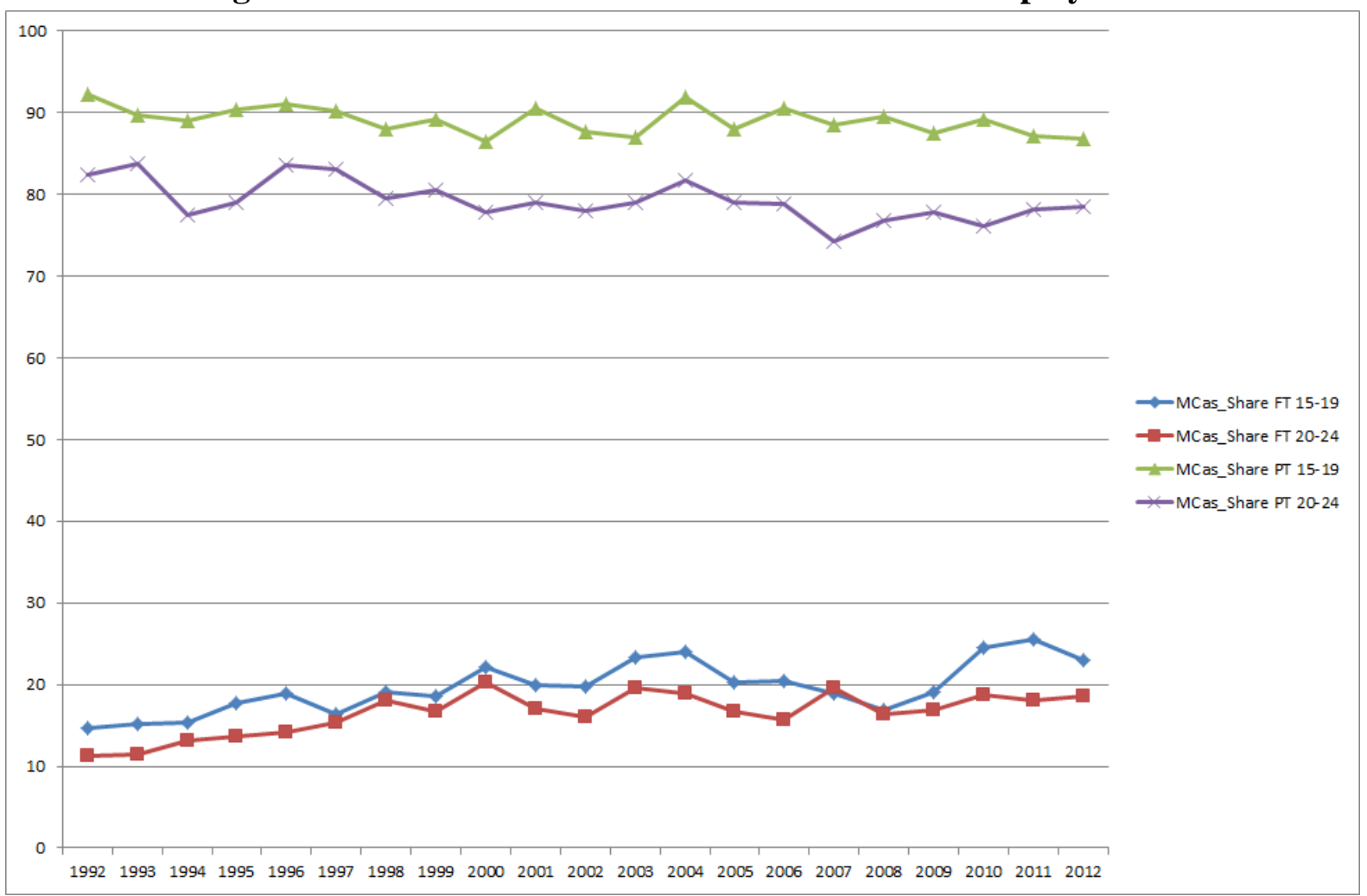

Source: ABS 6105.0 
Figure 5: Share of Female Casual Workers in Total Employment

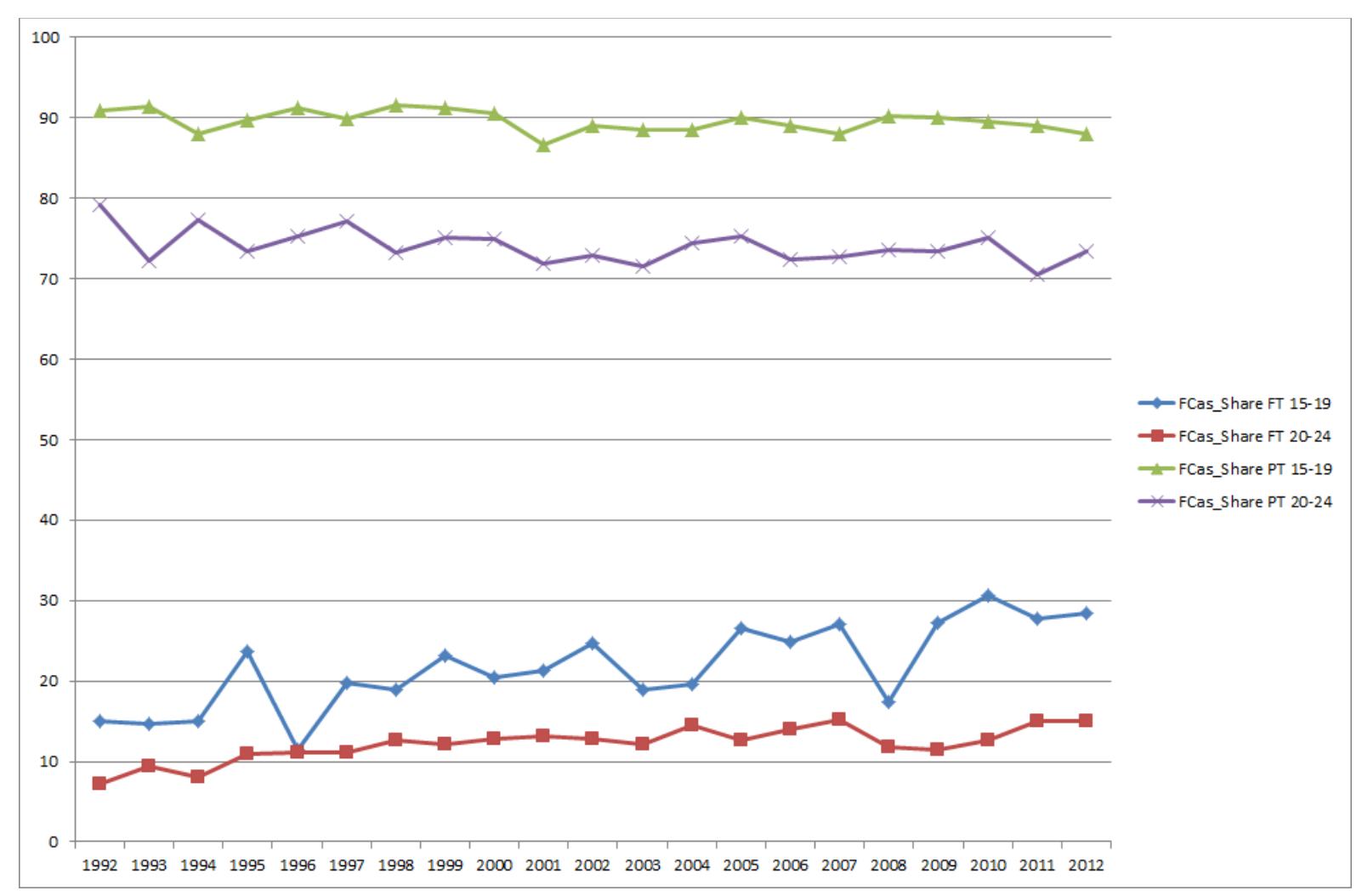

Source: ABS 6105.0

\section{The Youth Labour Market after the GFC}

Compared to most OECD countries, Australia fared much better and youth unemployment rates (15-24 year old) were almost the lowest, with only Japan and Germany that had lower rates. Even New Zealand which is sometimes listed as a country that has done well since the GFC, had higher unemployment rates. Greece and Spain have had increasingly high youth unemployment rates, while Germany was one of the few countries where youth unemployment rates continued to fall over this period. However, the increase in youth unemployment rates in Australia was higher than the OECD average, and higher than the US. 
Table 2: Youth Unemployment Rates 15-24, OECD

\begin{tabular}{|l|c|c|c|c|c|c|c|}
\hline & 2008 & 2009 & 2010 & 2011 & 2012 & 2013 & $\begin{array}{c}\% \\
\text { Increase }\end{array}$ \\
\hline Australia & 8.8 & 11.5 & 11.6 & 11.4 & 11.7 & 12.2 & 38.5 \\
\hline Canada & 11.6 & 15.2 & 14.8 & 14.2 & 14.3 & 13.7 & 18.0 \\
\hline France & 18.6 & 23.2 & 22.9 & 22.1 & 23.9 & 23.9 & 28.7 \\
\hline Germany & 10.4 & 11.0 & 9.7 & 8.5 & 8.1 & 7.9 & -23.7 \\
\hline Greece & 22.1 & 25.8 & 32.9 & 44.4 & 55.3 & $\mathbf{5 8 . 3}$ & 164.1 \\
\hline Ireland & 12.4 & 25.5 & 28.3 & 29.9 & 33.0 & 29.6 & 137.9 \\
\hline Italy & 21.3 & 25.4 & 27.9 & 29.1 & 35.3 & 40.0 & 88.2 \\
\hline Japan & 7.2 & 9.1 & 9.2 & 8.0 & 7.9 & $\mathbf{6 . 9}$ & -4.9 \\
\hline New Zealand & 11.4 & 16.6 & 17.1 & 17.3 & 17.7 & 15.8 & 38.9 \\
\hline Spain & 24.5 & 37.7 & 41.5 & 46.2 & 52.9 & 55.5 & 126.9 \\
\hline Sweden & 20.2 & 24.9 & 24.8 & 22.8 & 23.7 & 23.6 & 16.8 \\
\hline UK & 14.1 & 19.0 & 19.3 & 20.0 & 21.0 & 20.9 & 48.1 \\
\hline US & 12.8 & 17.6 & 18.4 & 17.3 & 16.2 & 15.5 & 21.0 \\
\hline OECD & 12.7 & 16.7 & 16.7 & 16.2 & 16.3 & 16.2 & 27.0 \\
\hline
\end{tabular}

\section{Source: OECD.Stat}

The Global Financial Crisis led to significant falls in GDP for most of the OECD countries, but Australia managed to grow throughout this period. Many economists (but not the National Bureau of Economic Research, New York) define a recession when a country faces two consecutive quarters of negative GDP growth. In terms of that definition, Australia avoided a recession. However, although Australian GDP fell only in one quarter during the GFC, unemployment rates (especially for youths) increased and have not returned to preGFC levels even by this date (August 2013), see Table 3 below. The youth labour market was hit badly by the GFC and unemployment and long term unemployment increased substantially for both males and females. However, since Australian GDP did not fall substantially, unemployment rates did not reach the very high levels that youths faced during the recession of the early eighties and the early nineties, see Figure 6. Similarly, youth underemployment rates (the unemployed plus those young people who would like to work longer hours), and youth underutilisation rates (the unemployed, plus the underemployed, plus the marginally attached to the labour force), see Figures 7 and 8 . This suggests that the problem for young people is more serious than simply looking at the unemployment rates. As a recession hits, the youth employment-population ratio falls (see Figure 9) both because unemployment rises and because the labour force participation rate falls (see Figure 10). Note that the female labour force participation rates had been growing consistently in previous decades and then fell, while the male labour force participation rates had been slowly falling and then dipped suddenly with the GFC. 
Table 3: Increases in Youth Unemployment in Australia, post-GFC (\%)

\begin{tabular}{|c|c|c|c|c|}
\hline & $\begin{array}{c}\text { MUR 15- } \\
\mathbf{1 9}\end{array}$ & $\begin{array}{c}\text { MUR 20- } \\
\mathbf{2 4}\end{array}$ & $\begin{array}{c}\text { FUR 15- } \\
\mathbf{1 9}\end{array}$ & $\begin{array}{c}\text { FUR 20- } \\
\mathbf{2 4}\end{array}$ \\
\hline Aug-08 & 10.2 & 5.6 & 9.9 & 4.9 \\
\hline Aug-13 & 16.4 & 9.8 & 13.6 & 8.6 \\
\hline $\begin{array}{c}\text { \% Increase since } \\
\text { GFC }\end{array}$ & 61.1 & 77.0 & 36.3 & 72.8 \\
\hline
\end{tabular}

Source: ABS Gross Flows (ST GM1)

Figure 6: Youth Unemployment Rates 15-24

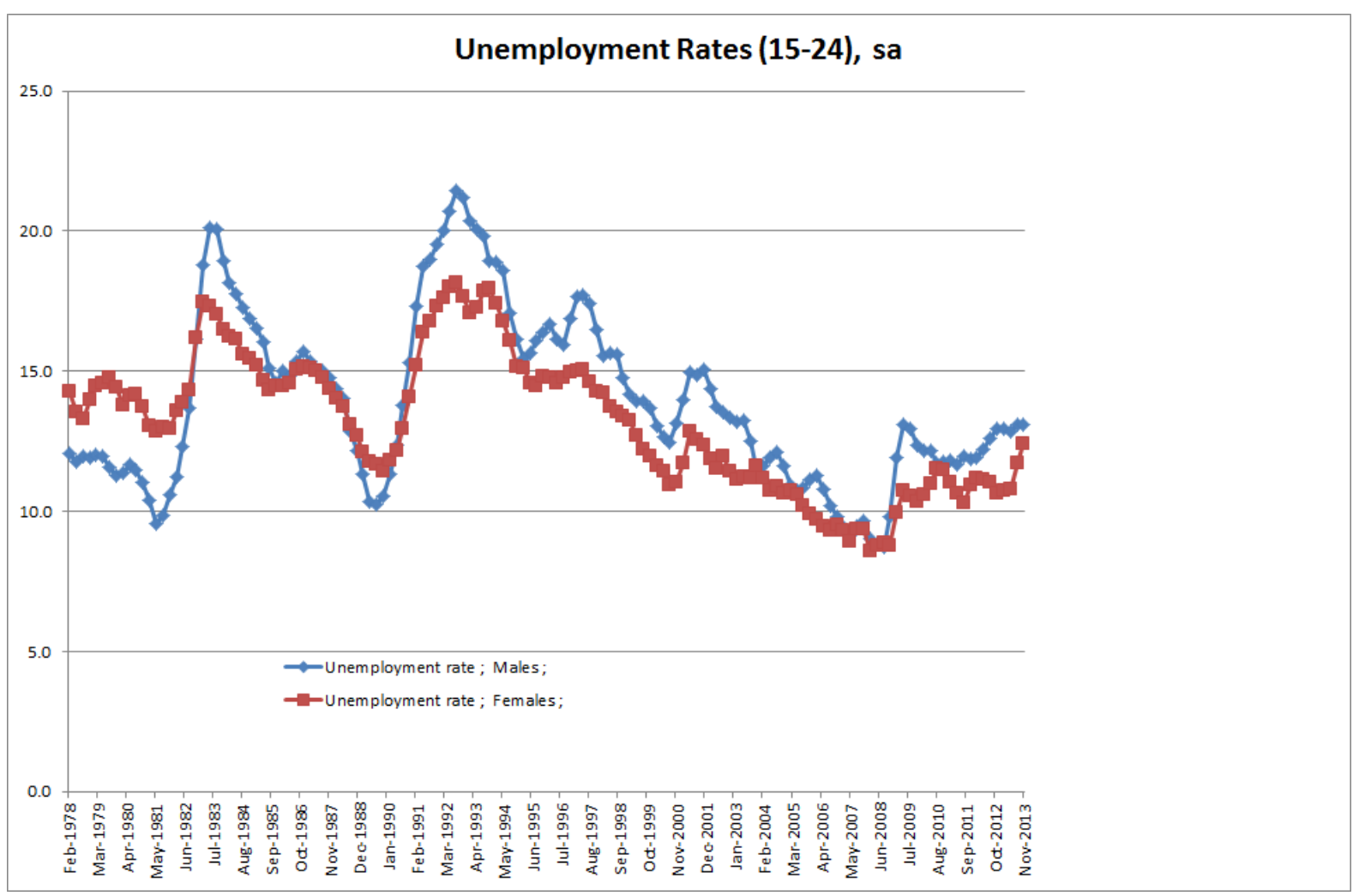

Source: ABS 6202.0 
Figure 7: Youth Underemployment Rates, 15-24

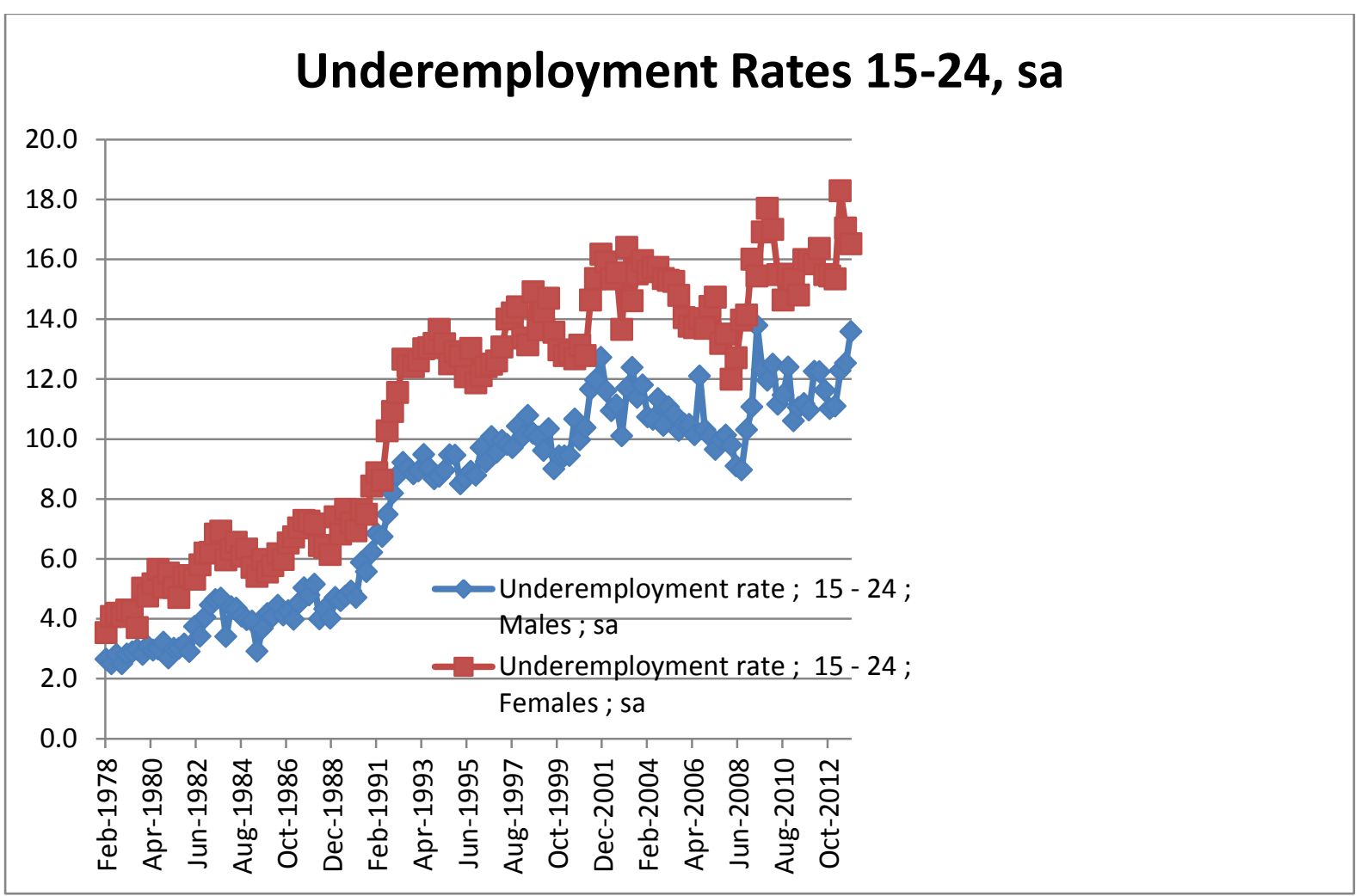

Figure 8: Youth Underutilisation Rates, 15-24

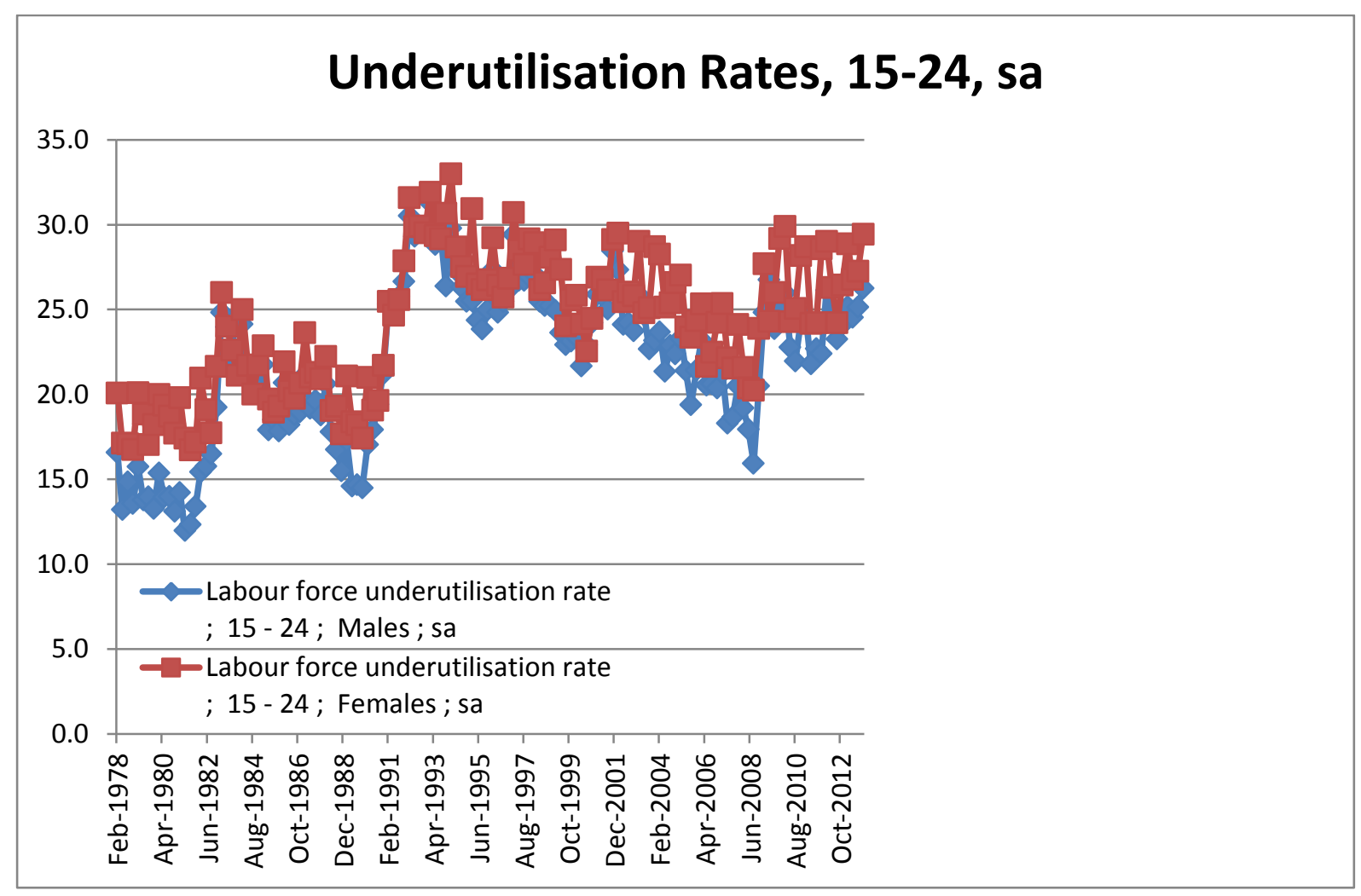

Source: ABS 6202.0, Table 22, 2013 
Figure 9: Youth Employment-Population Ratios

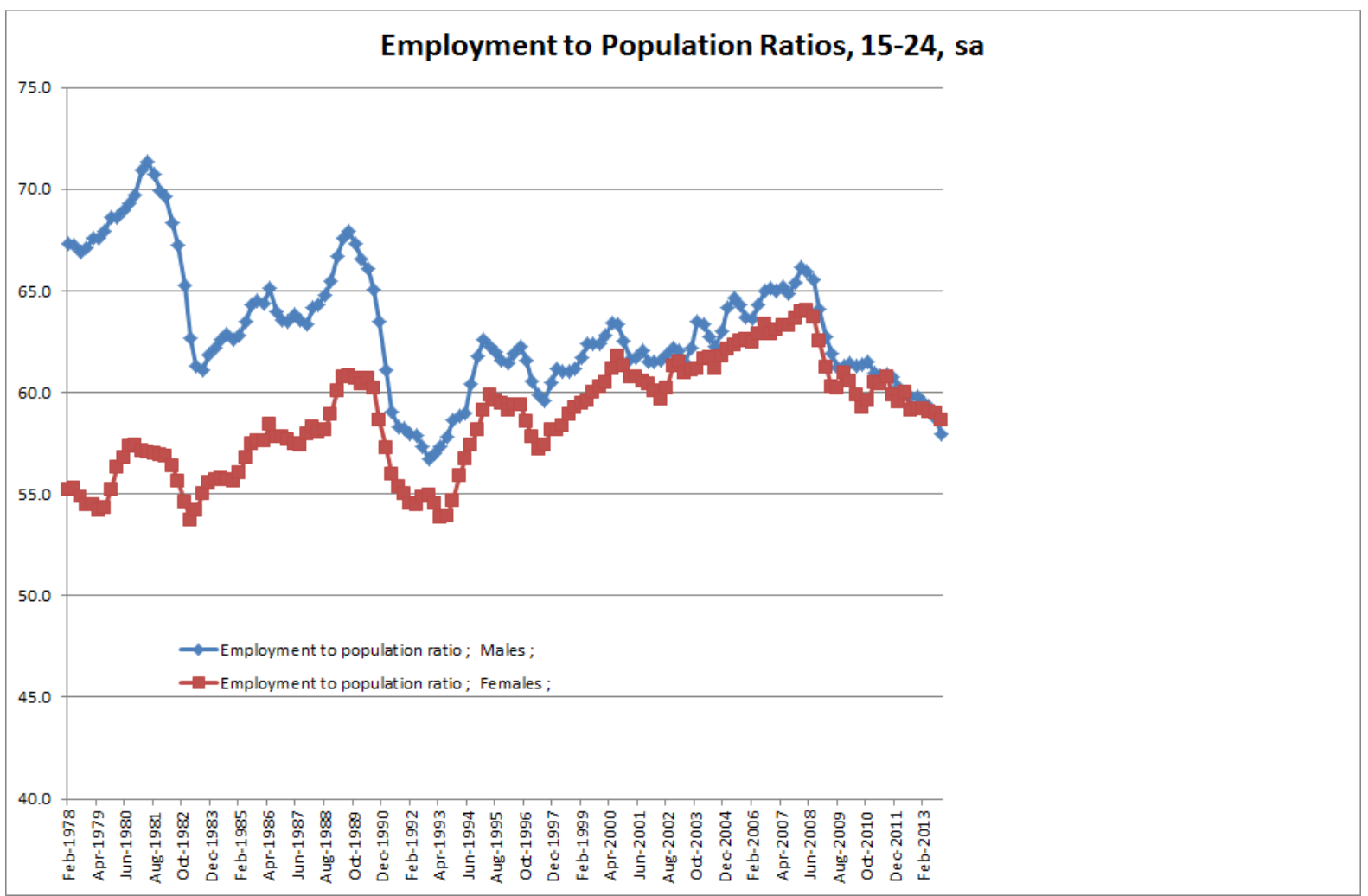

Source: ABS 6202.0 Labour Force, Australia, Table 17

Figure 10: Labour Force Participation Rates

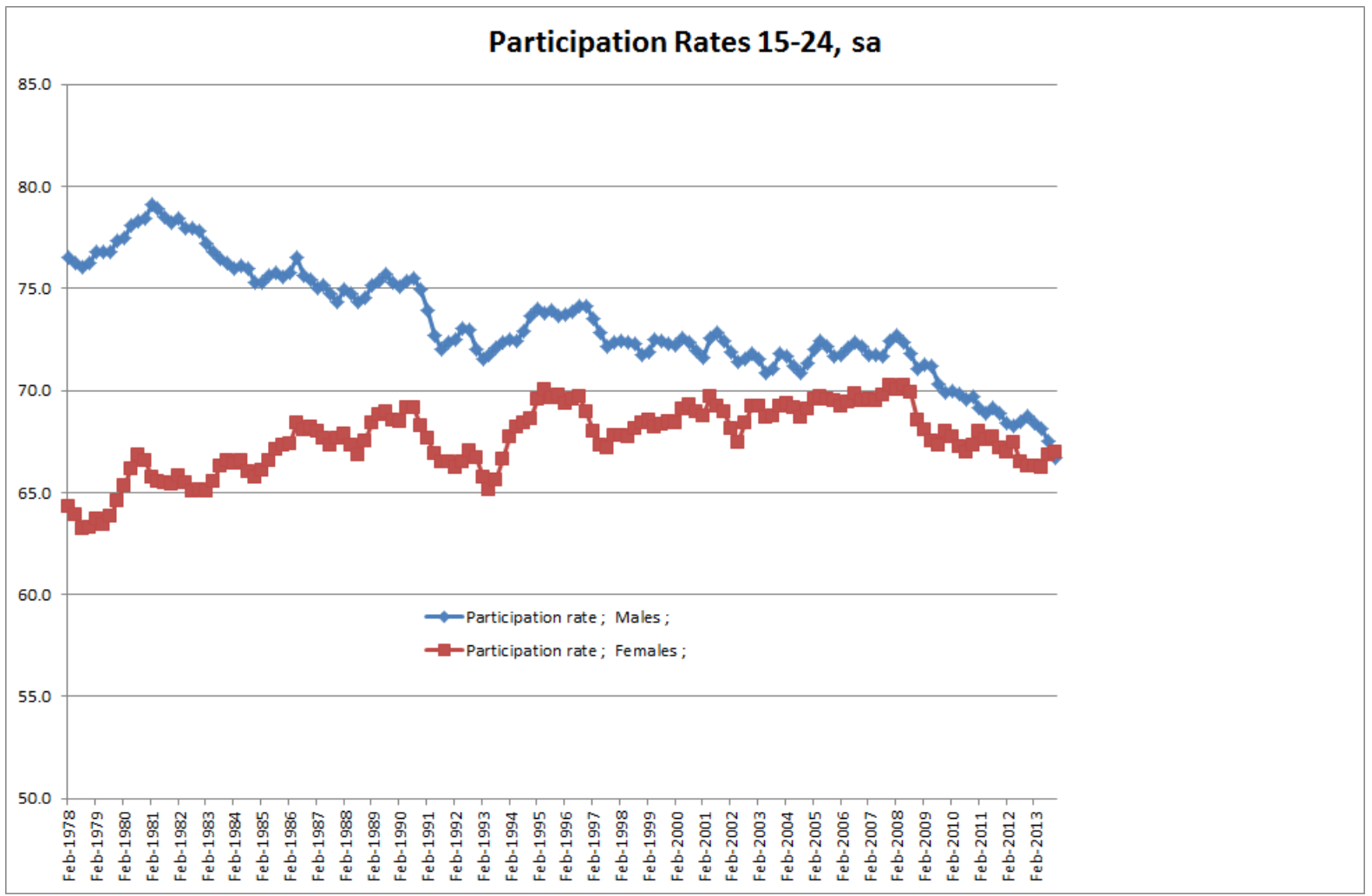

Source: ABS 6202.0 Labour Force, Australia, Table 17 
As the GFC hit, although we did not have a technical recession ${ }^{5}$ (two consecutive quarters of negative GDP growth) unemployment rates went up significantly for males, females, and youths. As discussed earlier, youths face significant increases in unemployment in recessions. The youth labour market is much more volatile than the adult labour market. In Figures 11 and 12 we have plotted moving variances (nine quarters) which clearly shows that youth unemployment rates are more volatile than adult unemployment rates. This is especially true for the younger youths in the 15-19 age group.

\section{Figure 11: Volatility of Youth and Adult Male Unemployment Rates}

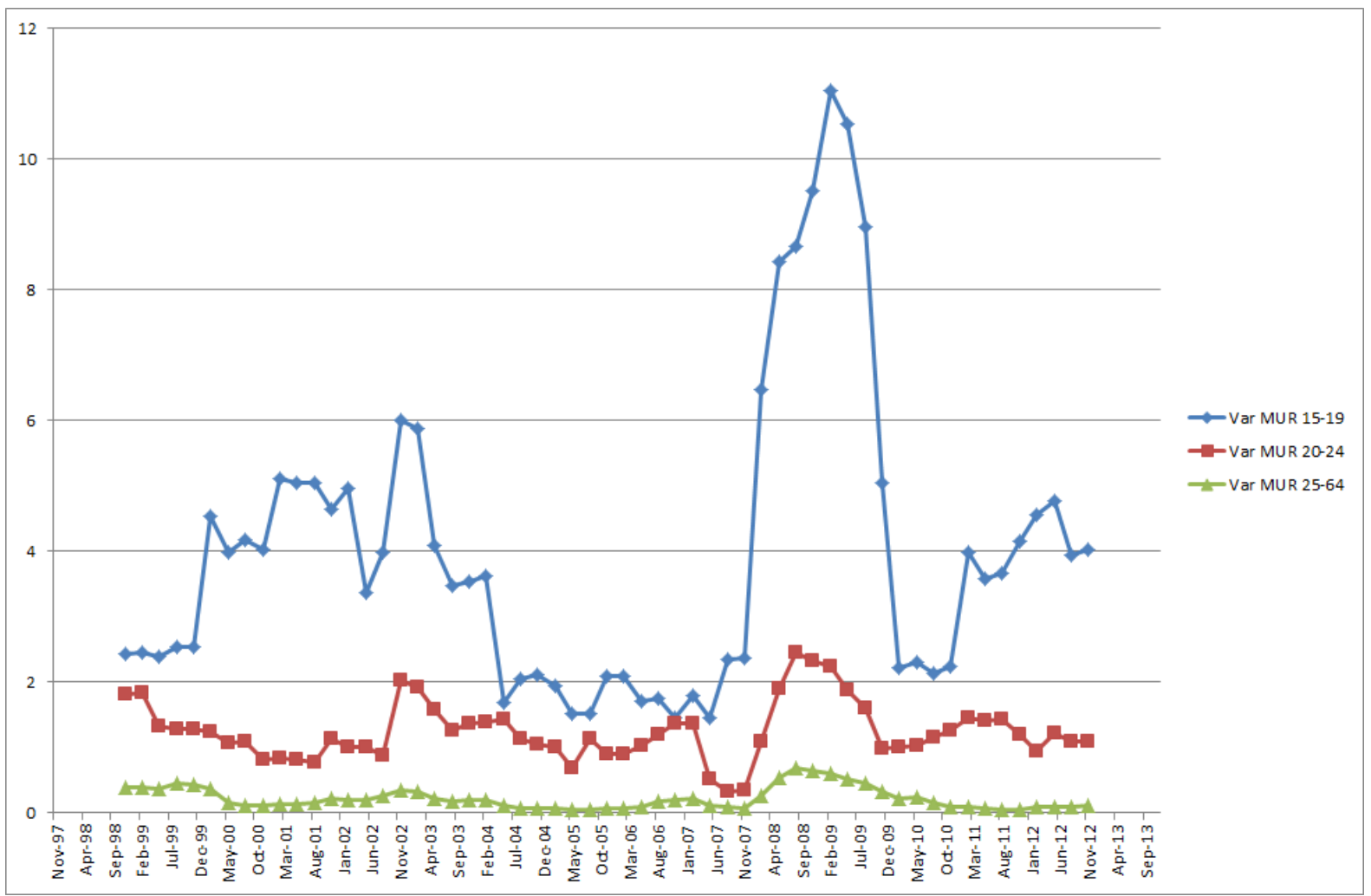

Source: ABS 7Gross Flows (ST GM1) Gross Flows by State, Age, Sex

\footnotetext{
${ }^{5}$ If you look at the seasonally adjusted data in ABS 5206.0 Australian National Accounts: National Income, Expenditure and Product, Table 1. Key National Accounts Aggregates we find that although Gross domestic product: Chain volume measures (seasonally adjusted) and Gross domestic product: Chain volume measures Percentage changes (seasonally adjusted) show GDP has negative growth for only one quarter in December 2008, the GDP Chain value Index (seasonally adjusted) has negative GDP growth for two consecutive quarters (from December 2008 with GDP at 93.1 falling to 92.0 in March 2009, and then to 90.0 in June 2009. The latter index suggested that Australia did have a technical recession!
} 
Figure 12: Volatility of Youth and Adult Female Unemployment Rates

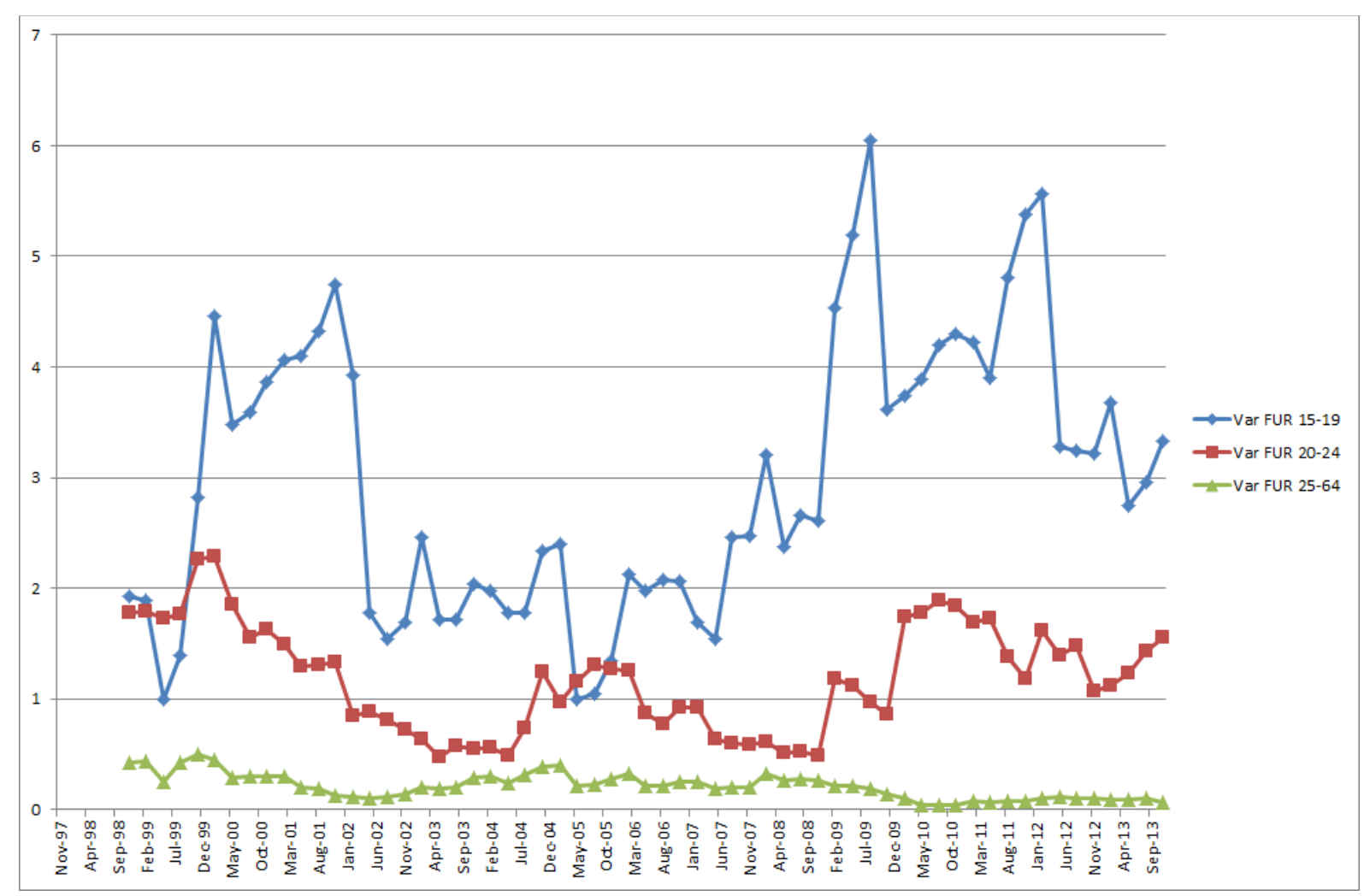

Source: ABS 7Gross Flows (ST GM1) Gross Flows by State, Age, Sex

When the GFC hit Australia, unemployment rates for adults and youths rose and so did the long term unemployed ${ }^{6}$. The percentage of the young unemployed who were unemployed for twelve months or more (incidence of long term unemployment) increased significantly (PLTU). Again, this long term unemployment has not returned to pre-GFC days (see Figures 13 and 14). It is worth noting that since some of the unemployed may give up looking for work and move into the education sector, so they do not become long term unemployed, which means that long term unemployment rates are under-estimated. Similarly, as youths age they may move out of the age group that is being considered (a person who is just 18 years old cannot be in the measured youth 8unemployed for more than a year). For a 20 year old youth, if s/he has been unemployed for one year, they have lost five percent of their life to date in unemployment, if they have been unemployed for two years they would have lost ten percent of their life in unemployment! Added to that is the problem of scarring: one spell of unemployment is likely to lead to repeat spells (see Junankar and Wood (1992), and to lower life-time earnings, see Clark et al. (2014). Is it surprising that the long term unemployed suffer from alienation, psychological problems, and depression?

\footnotetext{
${ }^{6}$ These data are for duration of unemployment since the last full time job. Data for a shorter period are available for durations since the last job. There are similarities although duration since last full time job is likely to be longer than since the last job.
} 
Figure 13: Incidence of Male Youth Long Term Unemployment (\%)

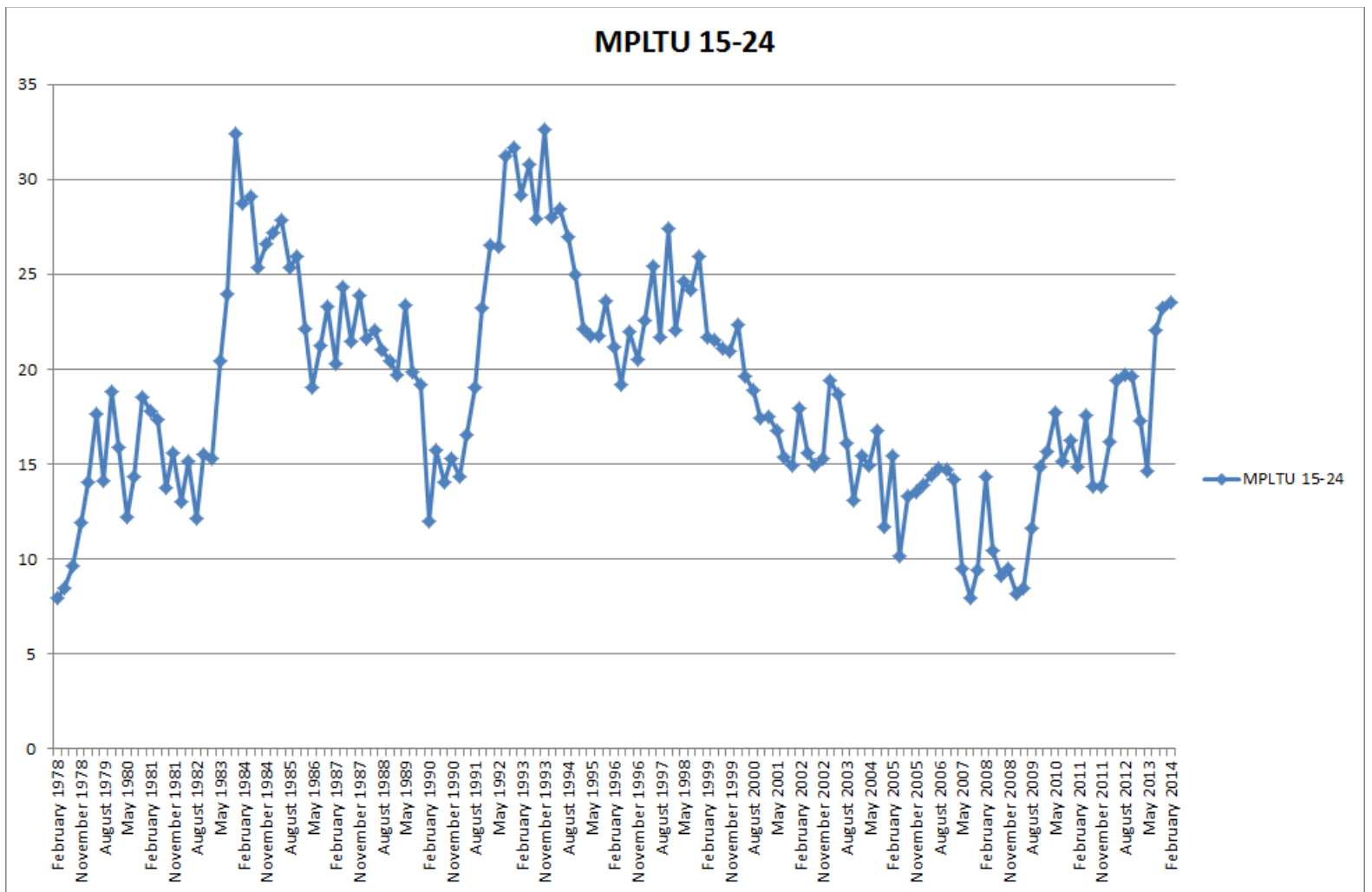

Source: ABS Unemployed persons (ST UM1) by State and Territory, Age, Sex and Duration of unemployment since last full-time job, February 1978 onwards.

Figure 14: Incidence of Female Youth Long Term Unemployment (\%)

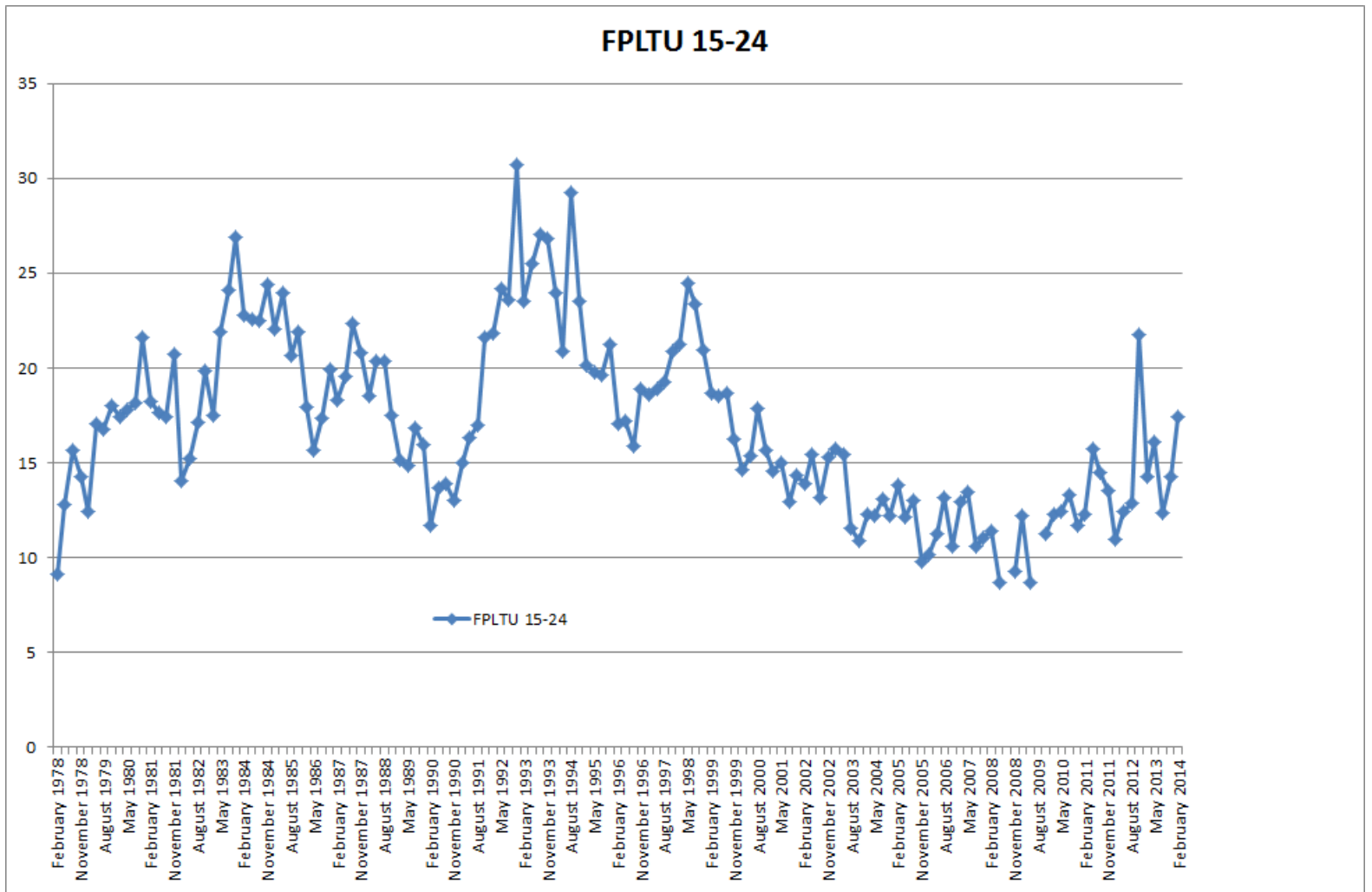

Source: ABS Unemployed persons (ST UM1) by State and Territory, Age, Sex and Duration of unemployment since last full-time job, February 1978 onwards. 


\section{What explains the rise in youth unemployment?}

What explains the rise in youth unemployment and long term unemployment? Although GDP growth was negative for only one quarter (but negative growth for two consecutive quarters in terms of the GDP index) in the aftermath of the GFC, the rate of growth of GDP slowed down subsequently, see Figure 15. Firms became cautious about hiring new workers and since a large proportion of the youths are first time entrants into the (full-time) labour market, they find it difficult to find work. Firms faced with a possible catastrophe not only stopped hiring new workers they also stopped renewing contracts of casual and part-time workers, these workers now joined the unemployment queue.

Figure 15: Gross Domestic Product Index (seasonally adjusted)

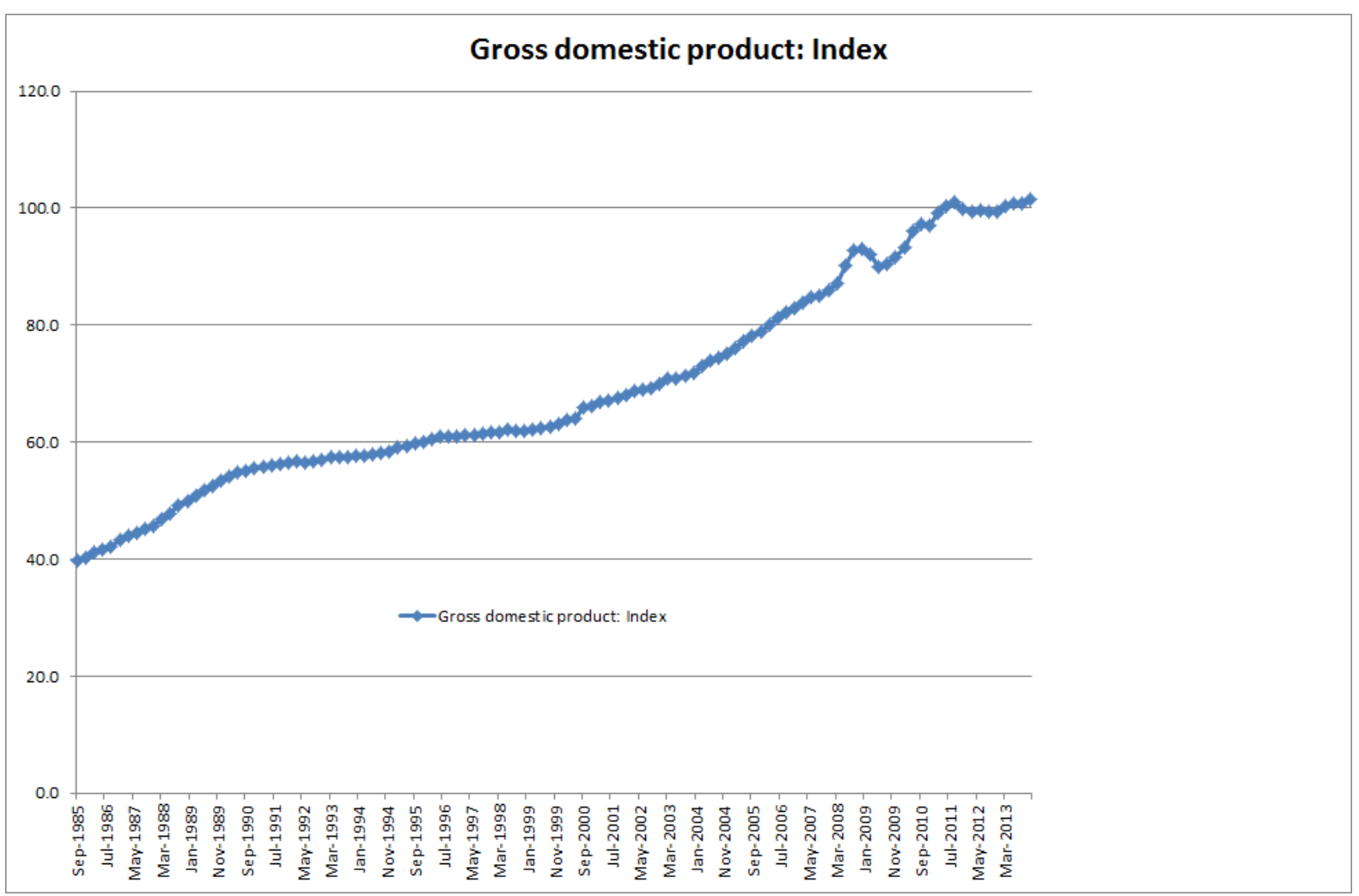

Source: ABS 5206.0

Most economists would agree that if the economy goes into a recession or if the growth rate of GDP slows down that it would lead to an increase in the overall unemployment rate. An Okun's Law relationship was estimated (change in the unemployment rate regressed on the growth rate) and found that the Okun coefficient was -0.40 suggesting that a one percent fall in the growth rate leads to a 0.40 percentage point increase in the unemployment rate. At the same time youth unemployment rates would also increase more than proportionately (by 0.60 percentage points as estimated above, see page 5). We can see that as Australian growth rates slowed down, youth unemployment rates went up significantly.

\section{Change in UR $=1.29-0.40$ Growth Rate}

$$
\begin{aligned}
& (11.1) \quad(-12.9) \\
& \mathrm{R}^{2}=0.54
\end{aligned}
$$


Many economists and employers' organisations argue that the growth of youth unemployment is due to either the high wages they have to pay (a high minimum wage) or because the unemployment-benefit system is "over-generous". There are always strident calls from the employer organisations that Australian minimum wages are too high compared to our competitive countries.

The controversy on the impact was kindled by the work of Card and Kreuger $(1994,1995)$ which was followed by several critiques (amongst others) by Neumark and Wascher (2007). In an earlier paper, Junankar, Waite and Belchamber (2000) we had estimated employment functions for youths in different industries (using time series data) and found no evidence to support the view that minimum wages decrease employment. Leigh (2003) in a study using difference in difference methodology compared one State (Western Australia that had increased minimum wages) with other States. He found a negative impact of minimum wages on employment. This paper was heavily criticised by Watson (2004) and by Junankar (2004). The international evidence is mixed with recent studies by Dube et al. (2010) for the USA showing that there is no evidence for the disemployment effects of minimum wages. One important issue that is sometimes ignored in cross-section studies is that if minimum wages are increased and that leads to an increase in total incomes of that group, then there would be Keynesian aggregate demand effects that can help to increase employment overall.

To evaluate these issues, we will study the movement of wages of youths relative to adults (or older workers), and also study the behaviour of the minimum wage relative to Average Weekly Earnings, and the movement of the replacement rate (ratio of unemployment benefits to AWE). 
Figure 16: Male Full time Earnings Ratios

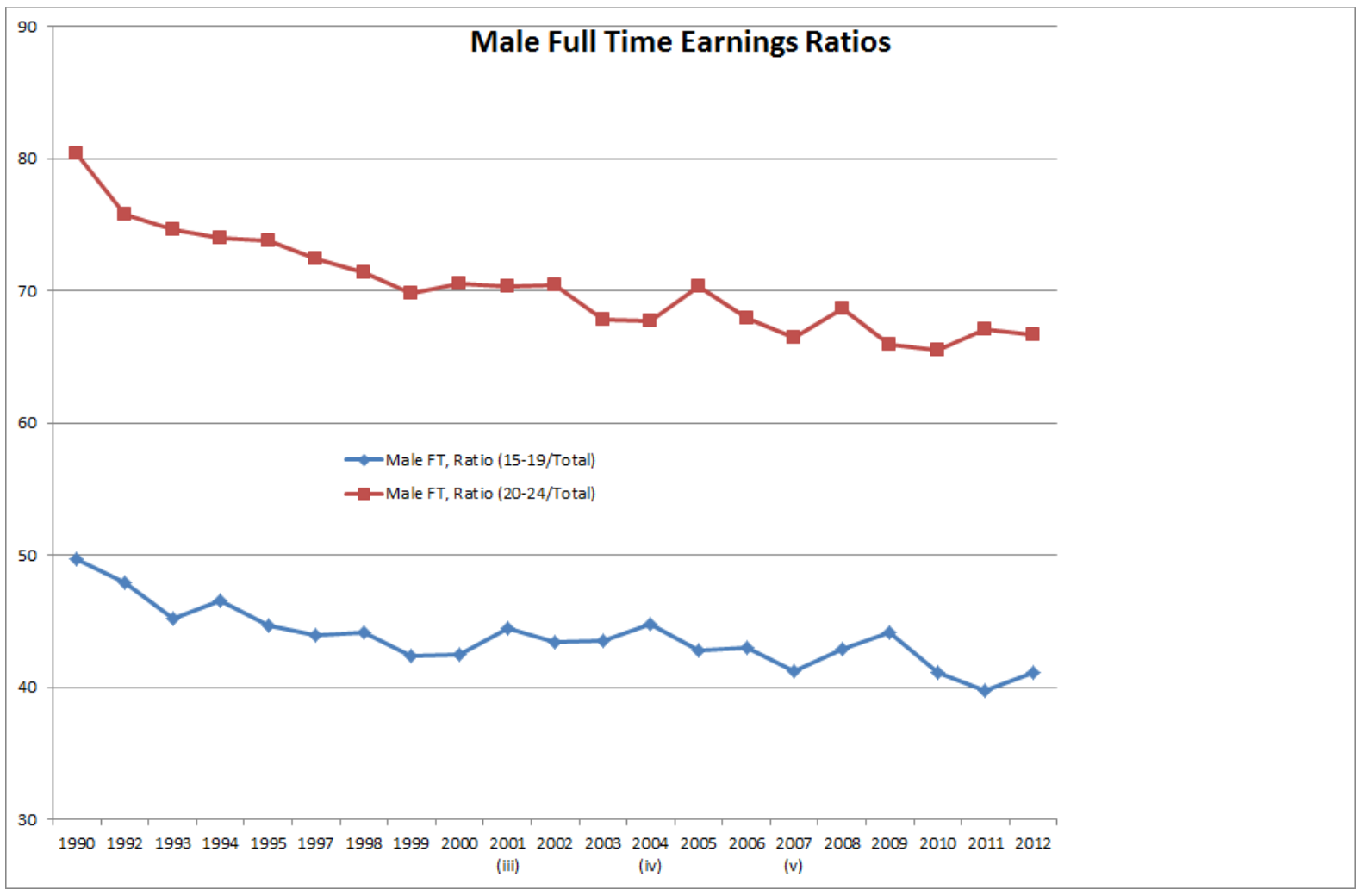

Source: ABS 63100, Employee Earnings, Benefits and Trade Union Membership, Australia Figure 17: Male Part time Earnings Ratios

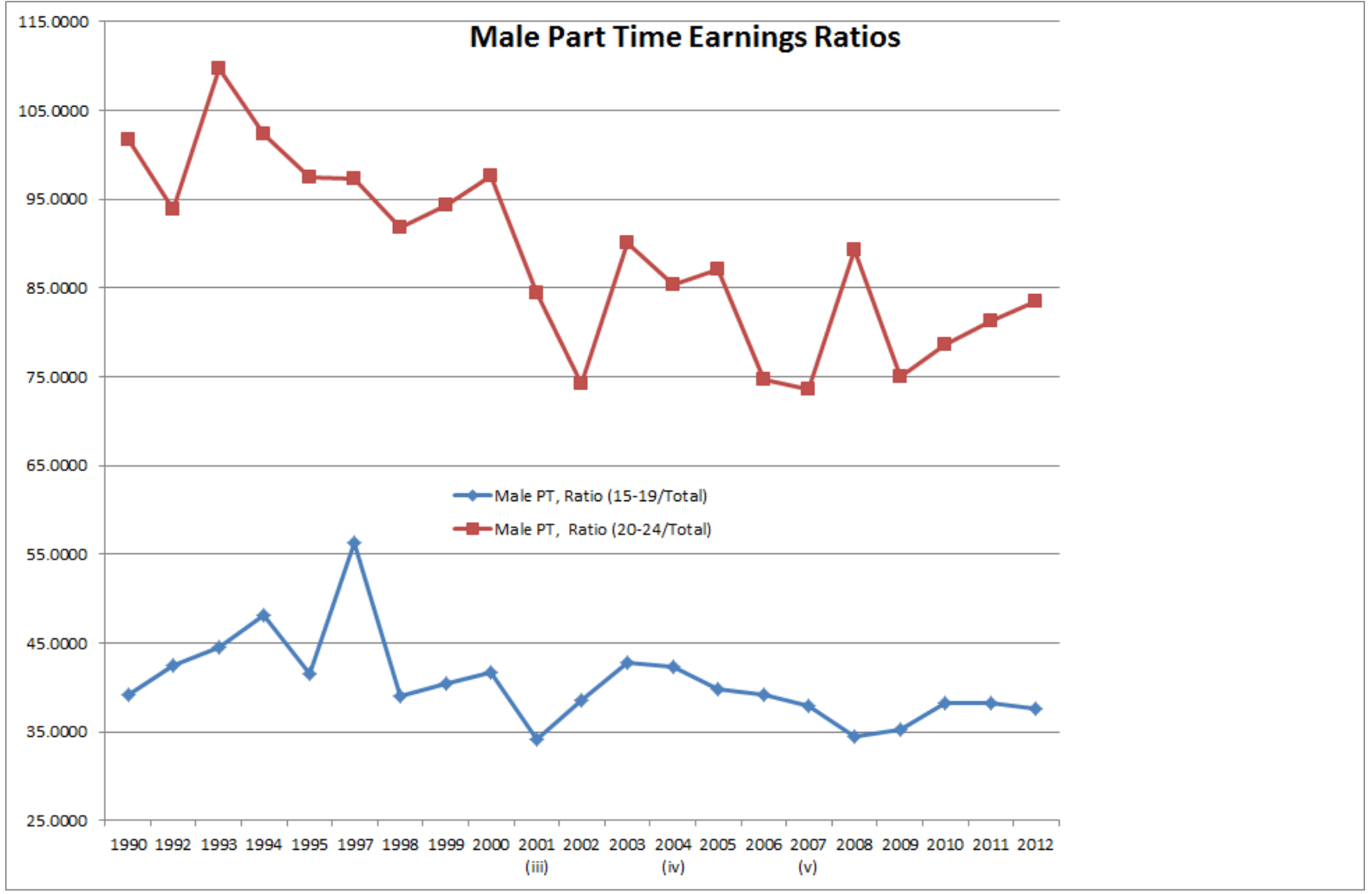

Source: ABS 63100, Employee Earnings, Benefits and Trade Union Membership, Australia 
Figure 18: Female Full Time Earnings Ratios

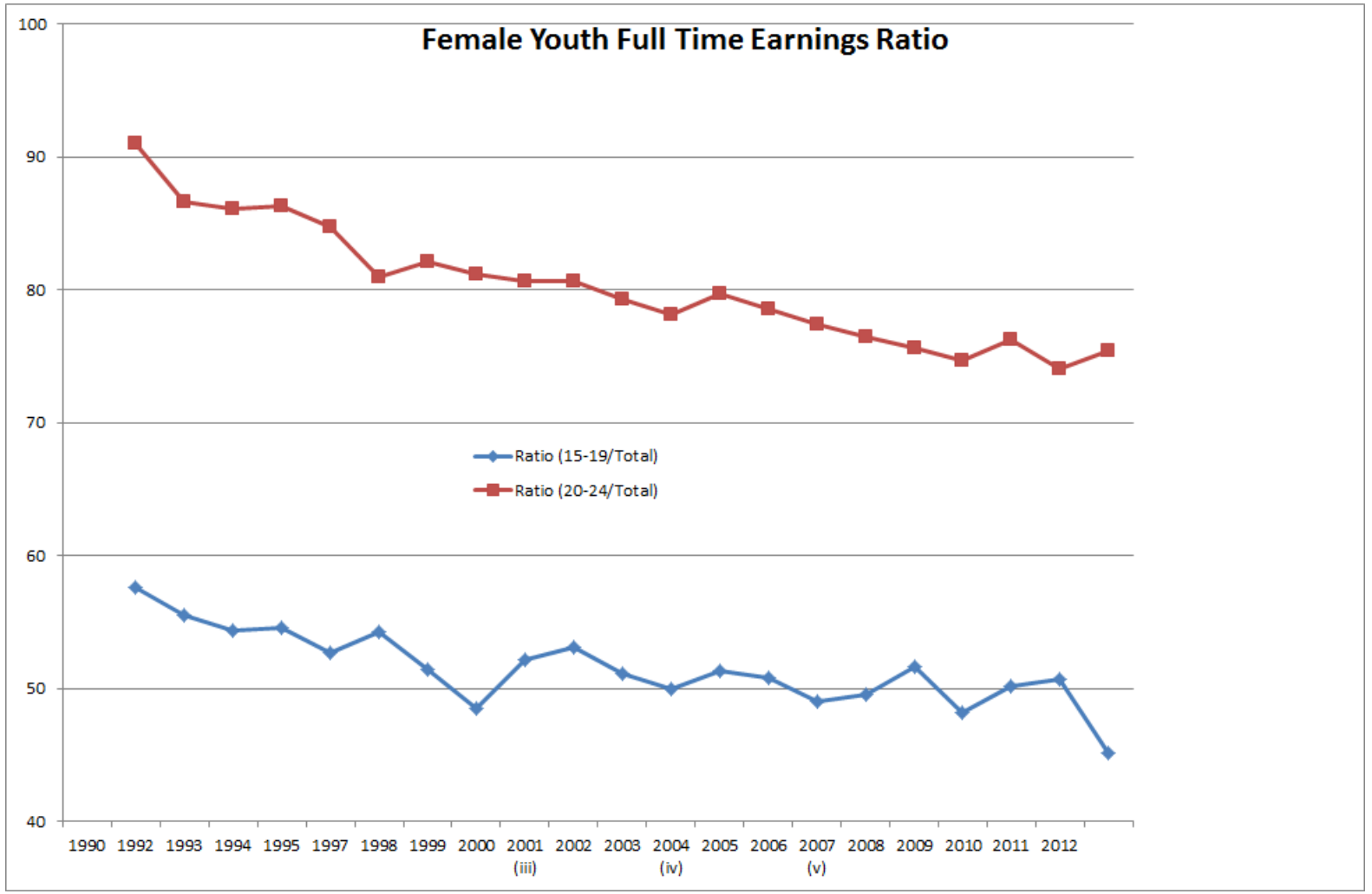

Source: ABS 63100, Employee Earnings, Benefits and Trade Union Membership, Australia

Figure 19: Female Part time Earnings Ratios

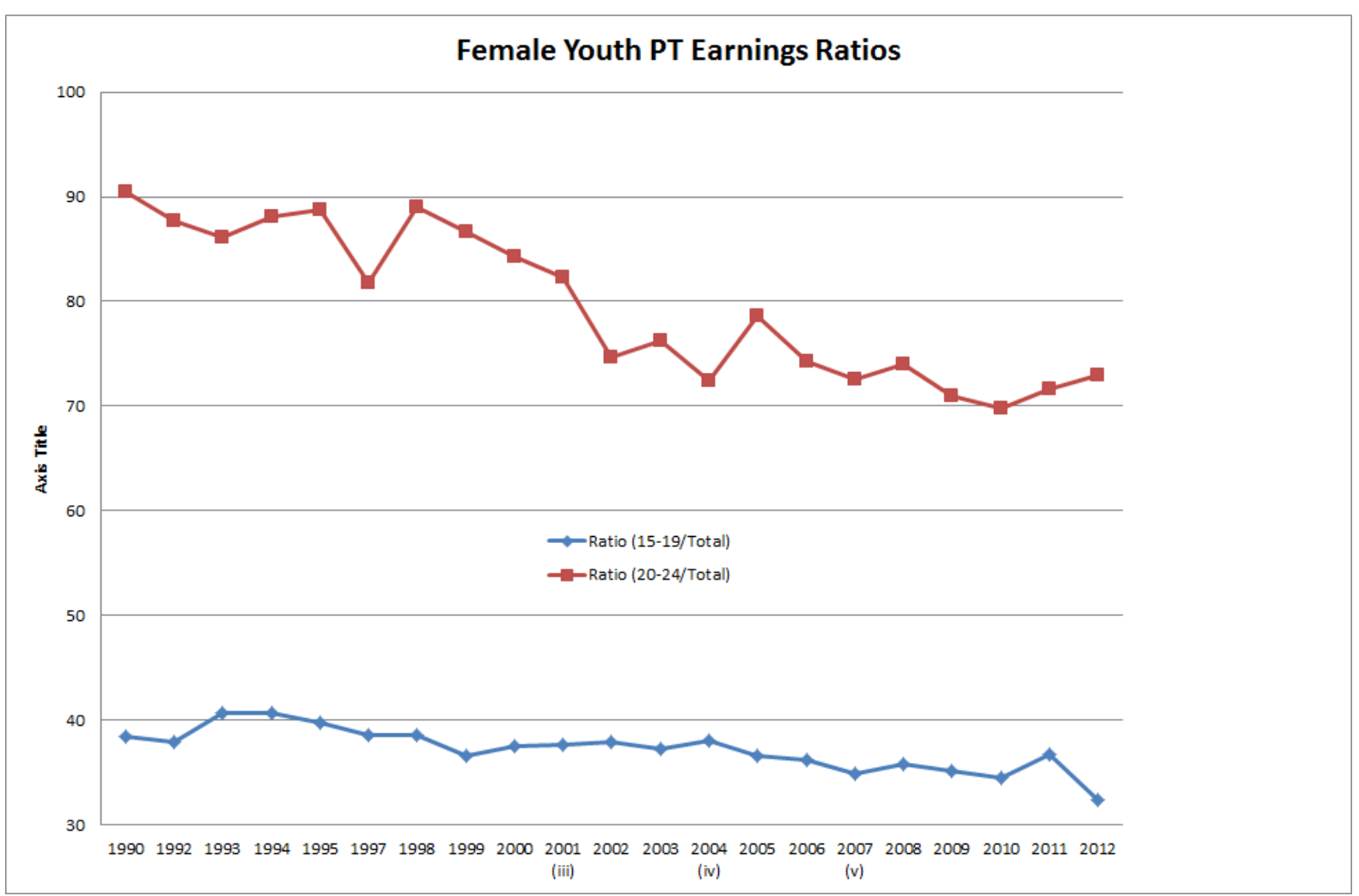

Source: ABS 63100, Employee Earnings, Benefits and Trade Union Membership, Australia 
Figures $16,17,18$, and 19 clearly show that youth wages relative to adult wages declined in 2008-2009, and were on a declining trend since the 1990s. This is true for both males and females. That suggests that the increase in youth unemployment rates were not due to youth wages being "too high". We are assuming that youth labour productivity had not fallen relative to adult labour productivity.

Another argument that is often raised is that the minimum wage is "too high" and hence employers are cutting back on employing young people. In Figures 20 and 21 we see that although the minimum wage was almost constant (increasing very slowly from 1998) unemployment rates for male and female youths had been falling continuously until the GFC. It is only after the GFC that unemployment rates increased while minimum wages increased slightly. This rejects the view that youth unemployment rates increase with minimum wages.

Figure 20: Male Youth Unemployment Rates and the Real Minimum Wage

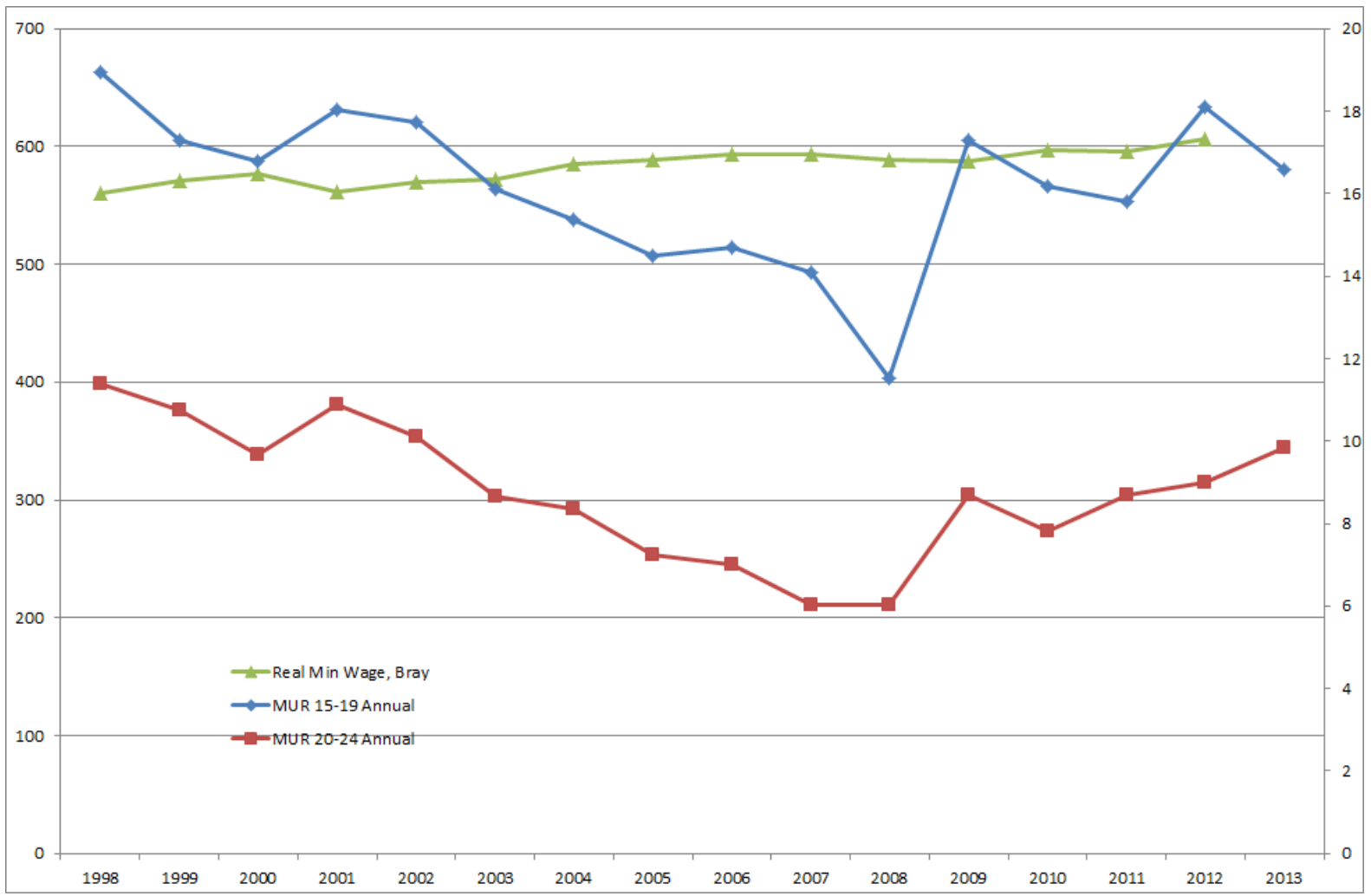

Source: Gross Flows (ST GM1) Gross Flows by State, Age, and Bray (2013)

Notes: The Real Minimum Wage data are from Bray (2013) and is on the left hand scale, while unemployment rates are represented on the right hand scale. 
Figure 21: Female Youth Unemployment Rates and the Real Minimum Wage

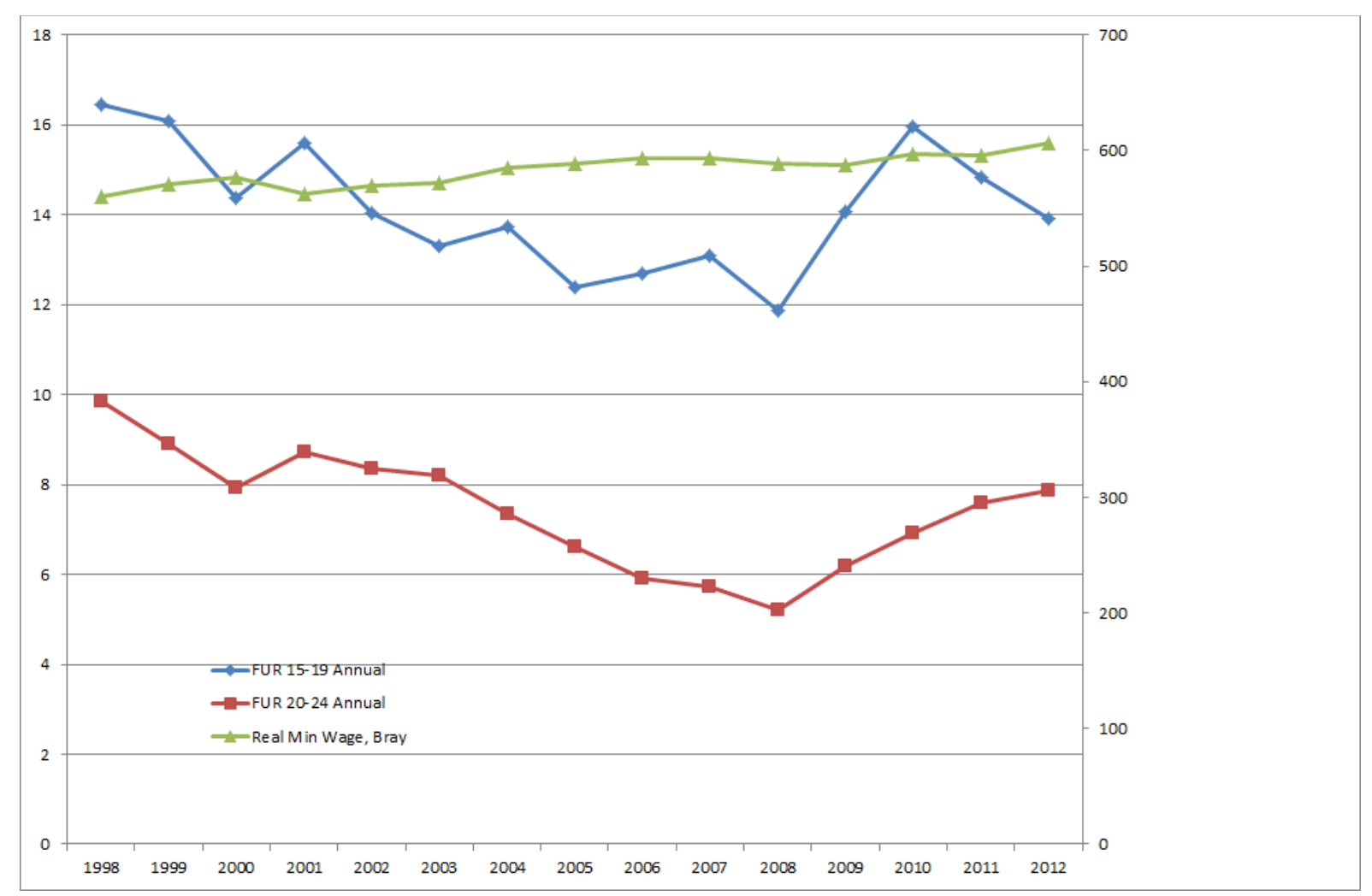

Source: ABS Gross Flows (ST GM1) Gross Flows by State, Age, and Bray (2013)

Notes: The Real Minimum Wage data are from Bray (2013) and is on the right hand scale, while unemployment rates are represented on the left hand scale.

We then study the possibility that unemployment benefits were too high compared to average weekly earnings, so that young people have no incentive to accept jobs. In general, according to search theory if the replacement rate ( $\mathrm{RR}$, ratio of unemployment benefits to expected wage rate) increases, unemployed searchers would become more "choosy" and reject job offers, hence unemployment goes up when RR increases. Analogously, if RR falls unemployment would fall. As Australia had been growing rapidly for several years (without a serious recession) unemployment rates had been falling and real wages increasing. However, in a recession we would find that the expected wage would fall and if unemployment benefits are constant ${ }^{7}$, the RR would rise! Note that the expected wage falls for two reasons: firstly, wage rates are likely to fall in a recession and secondly, the probability of finding a job offer falls, hence the expected wage (p(job) (wage)). In other words, the RR is endogenous ${ }^{8}$. Hence if we find that there is a positive relation between unemployment rates and RR it may be simply that unemployment rising is causing the RR to increase. In Figures 21 and 22 we see that as the RR falls so do unemployment rates. However, as discussed above the causation is from unemployment to replacement rates, not the other way round. Since the GFC, the RR is

\footnotetext{
${ }^{7}$ In fact real unemployment benefits had remained more or less constant for a decade or more.

${ }^{8}$ What would Kahneman say about this so-called rational choice? Do young people really go through this "system 2" thinking?
} 
still falling (at least for the over-21s) but unemployment rates are rising. There is no obvious relationship. ${ }^{9}$

Figure 21: Male Youth Unemployment Rates and Replacement Rates

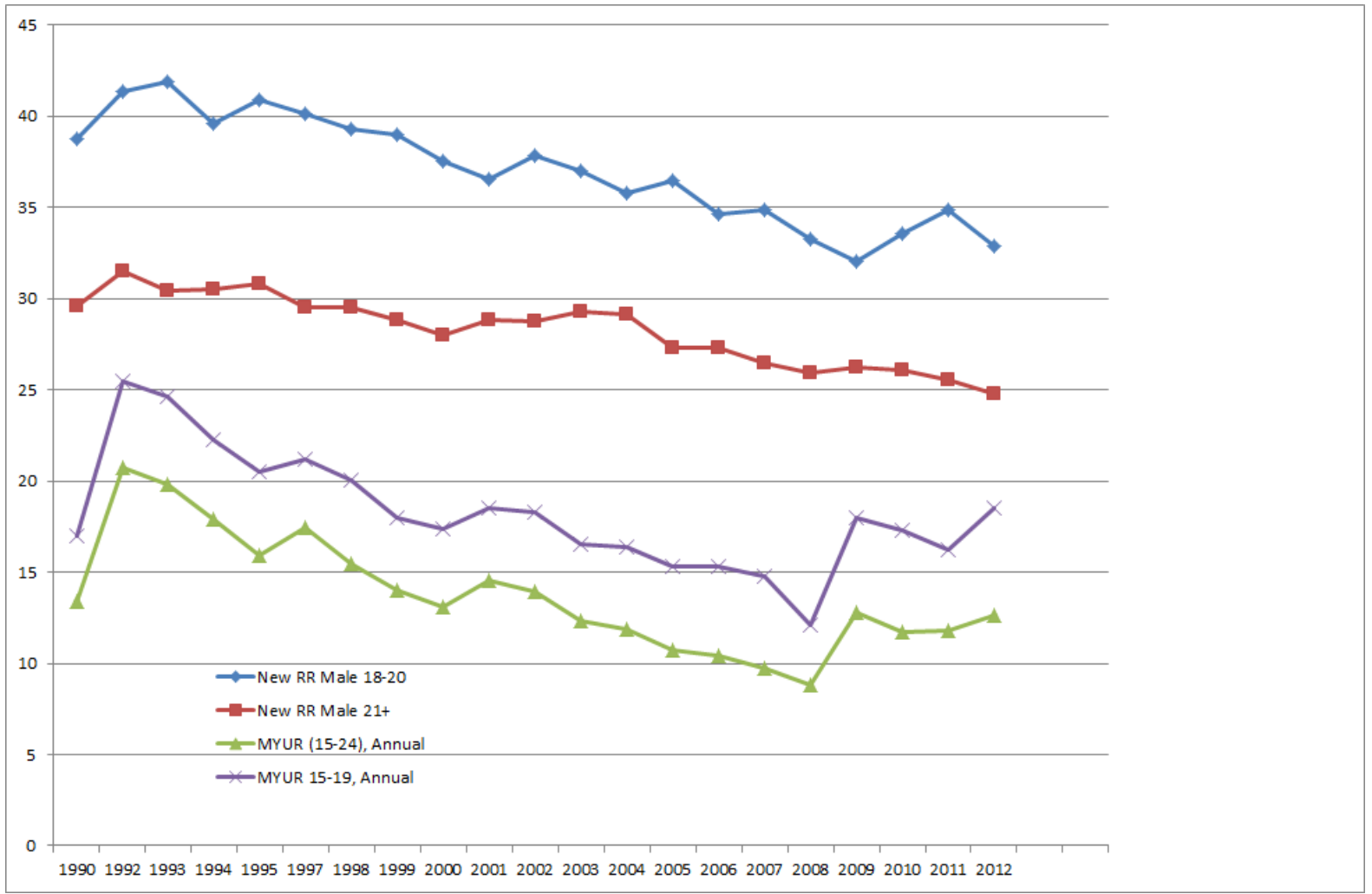

\footnotetext{
${ }^{9}$ Ideally, we need to have a complete econometric model to test for this relationship, allowing for the endogeneity of the replacement rate. However, the time series data on the youth labour market is not sufficiently rich for a rigorous examination. There have been numerous changes made to the rates of benefits paid and more importantly to the conditions under which these benefits were accessible. In an Honours thesis, my student Sewell (2013) showed that (with limited data) that there was no significant relationship between youth unemployment and RR.
} 
Figure 22: Female Youth Unemployment Rates and Replacement Rates

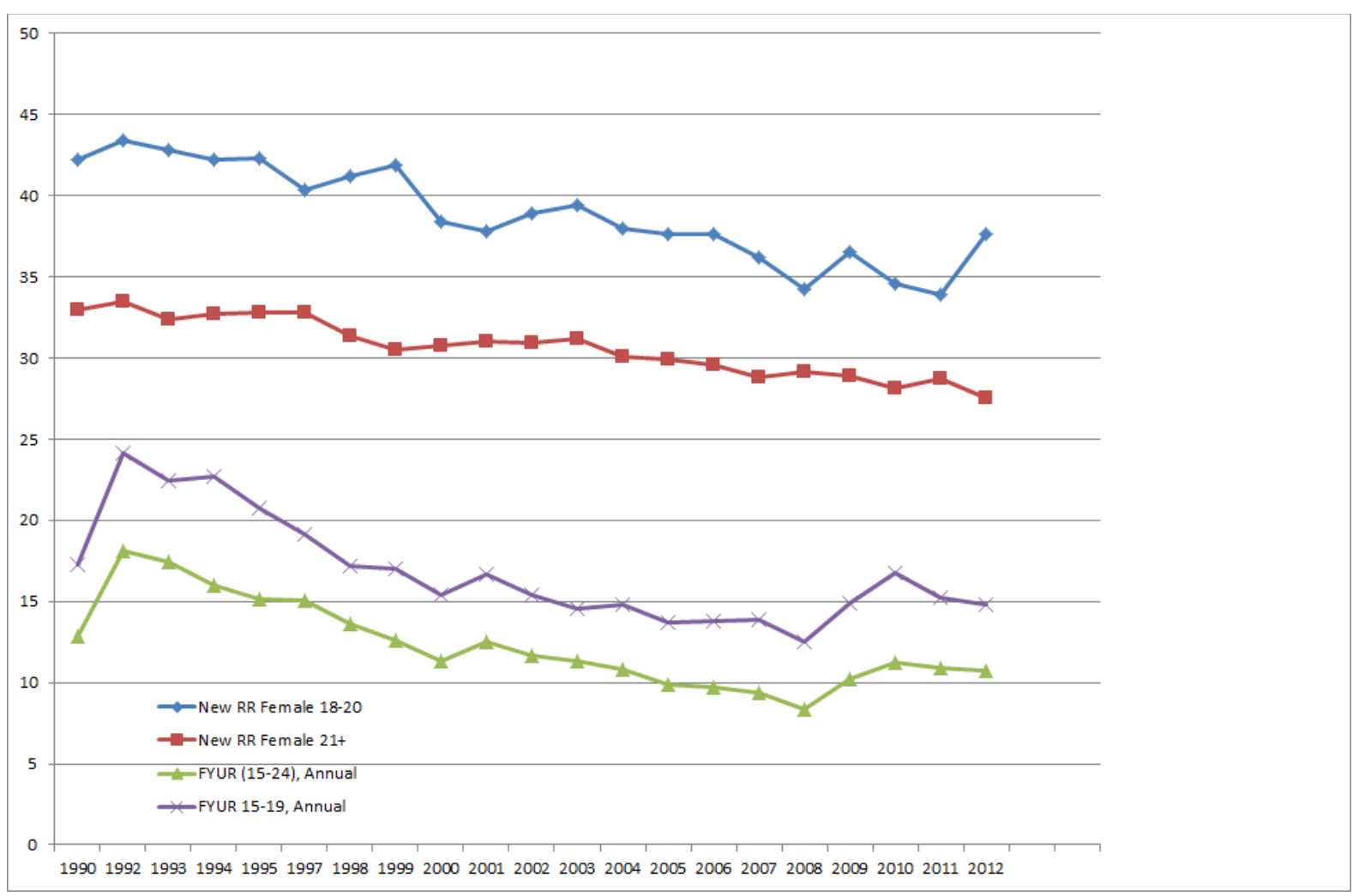

Source: ABS and Bray (2013)

\section{Conclusions}

In this paper we have studied the youth labour market and its response to the Global Financial Crisis. We showed that the youth labour market was significantly different from the adult labour market and more likely to be more volatile. Unemployment rates for youths increase more rapidly during a recession due to the fact that many young people are working in cyclically sensitive sectors, working in part-time casual employment. As a result, when a recession hits, employers stop hiring new entrants (the youths) and begin to fire youths as they are in vulnerable employment. We showed that the high youth unemployment could not be explained by high youth wages, by the minimum wage, or by so-called generous unemployment benefits.

If we would like to lower youth unemployment rates it is important to create increased growth, particularly in the industries that are the main employers of young people, namely, construction, manufacturing, retail trade and accommodation and food services for males, and retail trade, accommodation and food services, and health care and social assistance for females. Since manufacturing has been on a declining trend for decades, the main industries that would help young people would be a stimulus to (say) tourism that helps retail trade, accommodation and food services. In recent years there has been an increase in temporary visas for migrants (e.g. the backpackers, or 457 visas) who compete with youths in employment in restaurants, accommodation, etc. With an ageing population, there needs to be an increase in health services, this would increase the employment of young women as (say) 
nurses. To summarise, if the growth rate of the economy was stimulated it would decrease youth unemployment rates. In the context of a growing economy young people need to have greater access to apprenticeships and to on the job training schemes. ${ }^{10}$

The recent policies announced by the Abbott government would preclude young people (now defined by this government as anyone who is 30 years or less) from receiving unemployment benefits for the first six months and in the succeeding six months they would have to work for the dole if they did not find employment. In effect, the young are being excluded from the welfare system. There is clear evidence that work for the dole does not help the unemployed to find jobs and more importantly it has a negative effect on the participants in the scheme, see Jeff Borland and and Yi-Ping Tseng (2011). Given this evidence it is curious that the Abbott Government is requiring all unemployed people to go onto the Work for the Dole schemes. How these young people are expected to survive without any social security benefits is left to one's imagination. If they do not come from families with sufficient resources (and/or they are living independently) they will become homeless and either depend on charitable organisations or resort to petty crime. Is that the kind of society we would like to live in?

\footnotetext{
${ }^{10}$ To discuss the policies to help lower unemployment rates would require another paper. See Appendix for the OECD Action Plan for Youth, June 2013.
} 


\section{References}

Booth, Alison (2014) Wage Determination and Imperfect Competition, IZA Discussion Paper No. 8034 .

Borland, Jeff and Yi-Ping Tseng (2011) “Does 'Work for the Dole' work? An Australian perspective on work experience programmes", Applied Economics, 43 (28), 43534368.

Bray, J. Rob (2013) Reflections on the evolution of the minimum wage in Australia: options for the future paper, Crawford School of Public Policy, ANU.

Card, David \& Krueger, Alan, 'Minimum Wages and Unemployment: A Case Study of the Fast-Food Industry in New Jersey and Pennsylvania', American Economic Review, 1994, 84:4, 772-93

Card, David and Alan B. Krueger (1995) Myth and Measurement: The New Economics of the Minimum Wage. Princeton, N.J.: Princeton University Press.

Clark, Brian, Clement Joubert, and Arnaud Maurel (2014) “The Career Prospects of Overeducated Americans”, National Bureau of Economic Research, Working Paper 20167.

Cuervo, Hernán , Jessica Crofts \& Johanna Wyn (2013) “Generational insights into new labour market landscapes for youth”, Research Report 42, Youth Research Centre, Melbourne Graduate School of Education, University of Melbourne.

Daly, Anne, D. Nguyen-Hong, D. Eldridge, O. Gabbitas, and P. McCalman (1998) Youth Wages and Employment, Productivity Commission Staff Research Paper, AusInfo, Canberra.

Doiron, Denise \& Tue Gorgens (2008) "State dependence in youth labor market experiences, and the evaluation of policy interventions", Journal of Econometrics, 145, 81-97.

Dube, Arindrajit, T. William Lester and Michael Reich (2010) "Minimum Wage Effects Across State Boundaries: Estimates Using Contiguous Counties", Review of Economics and Statistics, 92 (4), 945-964. 
Eurofound (2014) Social situation of young people in Europe, Publications Office of the European Union, Luxembourg.

Heckman, James J. (2007) "Comments on Are Protective Labor Market Institutions at the Root of Unemployment? A Critical Review of the Evidence by David Howell, Dean Baker, Andrew Glyn, and John Schmitt," Capitalism and Society: Vol. 2: Iss. 1, Article 5.

Hérault, Nicolas, Weiping Kostenko, Gary Marks, \& Rezida Zakirova (2012) “The Effects of Macroeconomic Conditions on the Education and Employment Outcomes of Youth", Australian Journal of Labour Economics, 15(1), 17-36.

Howell, David R. (2010) Chapter 7: Institutions, Aggregate Demand and Cross-Country Employment Performance: Alternative Theoretical Perspectives and the Evidence, in Eckhard Hein and Engelbert Stockhammer, eds., A Modern Guide to Keynesian Macroeconomics and Economic Policies (Elgar)

Howell, David R. (Ed.) (2005) Fighting Unemployment: The Limits of Free Market Orthodoxy, Oxford University Press, Oxford.

Howell, David R., Dean Baker, Andrew Glyn, and John Schmitt (2007) “Are Protective Labor Market Institutions at the Root of Unemployment? A Critical Review of the Evidence", Capitalism and Society, 2 (1), 1-73.

Junankar, P.N \& Margaret Wood (1992) "The Dynamics of Unemployment: An Analysis of Recurrent Unemployment", in Youth in the Eighties: Papers from the Australian Longitudinal Surveys (Eds.) R.G. Gregory and T. Karmel, Canberra: Department of Employment, Education and Training \& Centre for Economic Policy Research, ANU, Canberra, 1992, (pp. 282-304).

Junankar, P.N. (Ed.) (1987) From School to Unemployment? The Labour Market for Young People. London: Macmillan 1987.

Junankar, P.N., M. Waite \& G. Belchamber (2000) "The Youth Labour Market: Anecdotes, Fables and Evidence" in Employment and Labour Relations Review, Supplement to Volume 11, 159-186. 
Junankar, P.N. 2004, '"Employment effects of minimum wages: Evidence from a quasiexperiment", by Andrew Leigh: A preliminary critique', in ACTU, Minimum Wages Case 2004, Tag Number 7 in Composite Exhibit, AIRC Safety Net Review, Melbourne.

Kahneman, Daniel (2011) Thinking Fast and Slow, New York: Farrar, Straus and Giroux.

Leigh, Andrew (2003) "Employment Effects of Minimum Wages: Evidence from a QuasiExperiment”, Australian Economic Review, 36 (4), 361-373.

Lewis, Phil \& McLean, Ben (1998) “The Youth Labour Market in Australia: A Survey”, Australian Journal of Labour Economics, 2:2, 1998, 158-72.

Manning, Alan (2003) Monopsony in Motion: Imperfect Competition in Labor Markets, Princeton University Press, Princeton, NJ.

Manning, Alan (2010) Imperfect Competition in the Labor Market, Chapter 11, Handbook of Labor Economics, Volume 4b, ed. by Orley Ashenfelter and David Card, Elsevier Science, Burlington.

Marks, G. N.; K. Hillman \& A. Beavis (2003). Dynamics of the Australian youth labour market : the 1975 cohort, 1996-2000. Melbourne: Australian Council for Educational Research (ACER)

Mavromaras, Kostas, Peter Sloane, and Zhang Wei (2013) “The Scarring Effects of Unemployment, Low Pay and Skills Under-utilisation in Australia Compared", IZA Discussion Paper No. 7440.

Miller, Paul and Paul Volker (1987) The Youth Labour Market in Australia, Economic Record, 63 (3), 203-219.

Mortensen, D.T. and C.A. Pissarides (1999) "New Developments in Models of Search in the Labor Market", in Handbook of Labor Economics, vol. 3, edited by O.C. Ashenfelter and D. Card, Amsterdam: North Holland.

Neumark, David \& Wascher, William, "Employment Effects of Minimum and Subminimum Wages: Panel Data on State Minimum-Wages Laws”, Industrial and Labor Relations Review, 46:1, 1992, 55-81. 
Neumark, David \& Wascher, William, "Minimum Wages and Unemployment”, IZA Discussion Paper Series, 2007, No. 2570.

Nickell, S. and R. Layard (1999) "Labor Market Institutions and Economic Performance”, in Handbook of Labor Economics, vol. 3, edited by O. Ashenfelter and D. Card, Elsevier, Amsterdam.

Nickell, S. and R. Layard (1999) "Labor Market Institutions and Economic Performance”, in Handbook of Labor Economics, vol. 3, edited by O. Ashenfelter and D. Card, Elsevier, Amsterdam.

O'Brien, M, (2006) "The Youth Labour Market in Australia - Implications From Work Choices Legislation”, Working Paper 06-08, Department of Economics, University of Wollongong.

Sewell, Chris (2013) “An Analysis of Youth Labour Markets”, Bachelor of Commerce, Honours Thesis, UNSW.

Solow, Robert (1990) The Labour Market as a Social Institution, Oxford: Blackwell.

Stewart, Mark (2007) "The Inter-related Dynamics of Unemployment and Low Wage Employment" Journal of Applied Econometrics, 22, 511-531.

Watson, Ian (2004) "Minimum wages and employment: Comment" Australian Economic Review 37 (2), 166-172. 


\section{Appendix}

\section{Source: OECD ACTION PLAN FOR YOUTH, June 2013}

\section{Box A1.1. Key elements of the OECD Action Plan for Youth}

Tackle the current youth unemployment crisis

- Tackle weak aggregate demand and boost job creation.

- Provide adequate income support to unemployed youth until labour market conditions improve but subject to strict mutual obligations in terms of active job search and engagement in measures to improve job readiness and employability.

- Maintain and where possible expand cost-effective active labour market measures including counselling, job-search assistance and entrepreneurship programmes, and provide more intensive assistance for the more disadvantaged youth, such as the low-skilled and those with a migrant background.

- Tackle demand-side barriers to the employment of low-skilled youth, such as high labour costs.

- Encourage employers to continue or expand quality apprenticeship and internship programmes, including through additional financial incentives if necessary.

\section{Strengthen the long-term employment prospects of youth}

- Strengthen the education system and prepare all young people for the world of work

- Tackle and reduce school dropout and provide second-chance opportunities for those who have not completed upper secondary education level or equivalent.

- Ensure that all youth achieve a good level of foundation and transversal skills.

- Equip all young people with skills that are relevant for the labour market.

- Strengthen the role and effectiveness of Vocational Education and Training

- Ensure that vocational education and training programmes provide a good level of foundation skills and provide additional assistance where necessary.

- Ensure that VET programmes are more responsive to the needs of the labour market and provide young people with skills for which there are jobs.

- Ensure that VET programmes have strong elements of work-based learning, adopt blends of work-based and classroom learning that provide the most effective environments for learning relevant skills and enhance the quality of apprenticeships, where necessary

- Ensure that the social partners are actively involved in developing VET programmes that are not only relevant to current labour market requirements but also promote broader employability skills.

- Assist the transition to the world of work

- Provide appropriate work experience opportunities for all young people before they leave education.

- Provide good quality career guidance services, backed up with high quality information about careers and labour market prospects, to help young people make better career choices.

- Obtain the commitment of the social partners to support the effective transition of youth into work, including through the development of career pathways in specific sectors and occupations.

- Reshape labour market policy and institutions to facilitate access to employment and tackle social exclusion

- Ensure more equal treatment in employment protection of permanent and temporary workers, and provide for reasonably long trial periods to enable employers to give youth who lack work experience a chance to prove themselves and encourage transition to regular employment

- Combat informal employment through a comprehensive approach.

- For the most disadvantaged youth, intensive programmes may be required with a strong focus on remedial education, work experience and adult mentoring. 